\title{
Hydrochemical characteristics of bulk meltwater from an entire ablation season, Longyearbreen, Svalbard
}

\author{
Jacob C. YDE, ${ }^{1}$ Mette RIGER-KUSK, ${ }^{1,2}$ Hanne H. CHRISTIANSEN, ${ }^{2}$ \\ N. TVis KNUDSEN, ${ }^{1}$ Ole HUMLUM ${ }^{3}$ \\ ${ }^{1}$ Department of Earth Sciences, University of Aarhus, Ny Munkegade bygning 520, DK-8000 Aarhus, Denmark \\ E-mail: yde@phys.au.dk \\ ${ }^{2}$ Department of Geology, The University Centre in Svalbard (UNIS), Box 156, NO-9171 Longyearbyen, Norway \\ ${ }^{3}$ Department of Geosciences, University of Oslo, PO Box 1042, Blindern, N-0316 Oslo, Norway
}

\begin{abstract}
The ionic and isotopic characteristics of bulk waters emanating from the cold-based Longyearbreen, central Svalbard, in 2004 are examined to determine lithological, hydrological and glaciological controls on water composition, solute provenance and chemical denudation. The geology consisted of reactive coal seams and associated sedimentary rocks. Acidity caused by microbialmediated oxidation of sulfides and, to a lesser extent, nitrogen-bearing minerals was neutralized by congruent dissolution of dolomite and incongruent weathering of silicates in open-system subglacial drainage channels. The ablation season was divided into an early melt season, a peak-flow period and a late melt season. The runoff distribution during these periods was $1.7 \%, 89.7 \%$ and $8.6 \%$, respectively, whereas the solute flux distribution was $1.9 \%, 82.1 \%$ and $16.0 \%$, respectively. Comparisons between different annual solute flux estimation methods indicated that extrapolation of peak-flow period data significantly underestimated both the early- and late-melt-season solute fluxes. About $3.8 \%$ of the solutes derived from sea-salt spray, $0.7 \%$ from acid aerosol deposition and $95.5 \%$ from crustal/organic sources. The physical and chemical conditions resulted in diffusion of $\mathrm{CO}_{2}$ rather than atmospheric drawdown. The cation-equivalent weathering rate and the crustal solute yield were $322 \Sigma \mathrm{mEq}^{+} \mathrm{m}^{-2} \mathrm{a}^{-1}$ and $22 \mathrm{t} \mathrm{km}^{-2} \mathrm{a}^{-1}$, respectively, which are within the regional range of Svalbard. However, the chemical weathering intensity was as high as $940 \Sigma \mathrm{mEq}^{+} \mathrm{m}^{-3}$ owing to the relatively low specific discharge of $0.34 \mathrm{ma}^{-1}$.
\end{abstract}

\section{INTRODUCTION}

The study of water chemistry in glacierized catchments contributes to our knowledge of the cryospheric influence on past and present chemical denudation and elemental cycling (Kump and Alley, 1994; Tranter 1996, 2006; Jones and others, 1999; Brown, 2002) and glacial ecosystems (Sharp and others, 1999; Skidmore and others, 2000, 2005; Hodson and others, 2004, 2005; Mikucki and others, 2004; Wadham and others, 2004; Tranter and others, 2005). Chemical weathering rates in glacial environments have been found to exceed global mean rates owing to relatively high specific runoff (Anderson and others, 1997) and high physical erosion rates (Anderson, 2005). However, the range of biogeochemical studies of glacial waters has been restricted to relatively few glaciers, making generalizations vulnerable to site-specific conditions (see reviews by Hodson and others, 2000; Brown, 2002; Tranter, 2003, 2006). Complex relations between factors such as climate, lithology, glacier morphology, basal thermal regime, drainage pathways and biological activity control the chemical composition, solute provenance and chemical weathering intensity in glacierized catchments. Spatial and temporal changes in any of the controlling factors reflect short- to long-term variations in the hydrochemistry. Consequently, a wide variety of hydrochemical characteristics exist, forming a continuum between end-member glacial settings. It is therefore of major significance to examine glacier hydrology and hydrochemistry in contrasting glaciological and geological environments.
This study of bulk meltwater hydrochemistry at Longyearbreen, Svalbard, differs from previous studies of glacier hydrochemistry in that it considers weathering processes of coal seams and associated sedimentary deposits and rocks which expose reactive mineral surfaces and dispersed organic matter. Drainage from areas with natural weathering of coal resembles acid mine drainage, where flushing waters are acidified by decomposition, frequently microbially catalyzed, of sulfides and, to a much lesser extent, nitrides (Ingram and Rimstidt, 1984). Such waters are characterized by low $\mathrm{pH}$ and high concentrations of metals and sulfates (Wieder and Lang, 1984; Holm and others, 2003). At Longyearbreen, the acidification is neutralized by the presence of carbonates, making the resultant waters distinguishable from previously studied glacial waters by high concentrations of crustally derived sulfates and nitrates.

This paper aims to elucidate the hydrochemical characteristics of bulk waters emanating from Longyearbreen during an entire ablation season from May to September; to relate the meltwater hydrochemistry to snow chemistry collected before the runoff season commenced and to subglacial-water chemistry after runoff ceased; to determine lithological, hydrological and glaciological controls; and to assess potential errors caused by extrapolation of ion concentrations done in order to estimate annual fluxes. The latter is possible because sampling continued throughout an entire ablation season and no proglacial naled (also referred to as icing or aufeis) formation occurred. The findings at Longyearbreen illustrate the enormous range in ionic concentrations, fluxes and provenance in glacial riverine chemistry. 


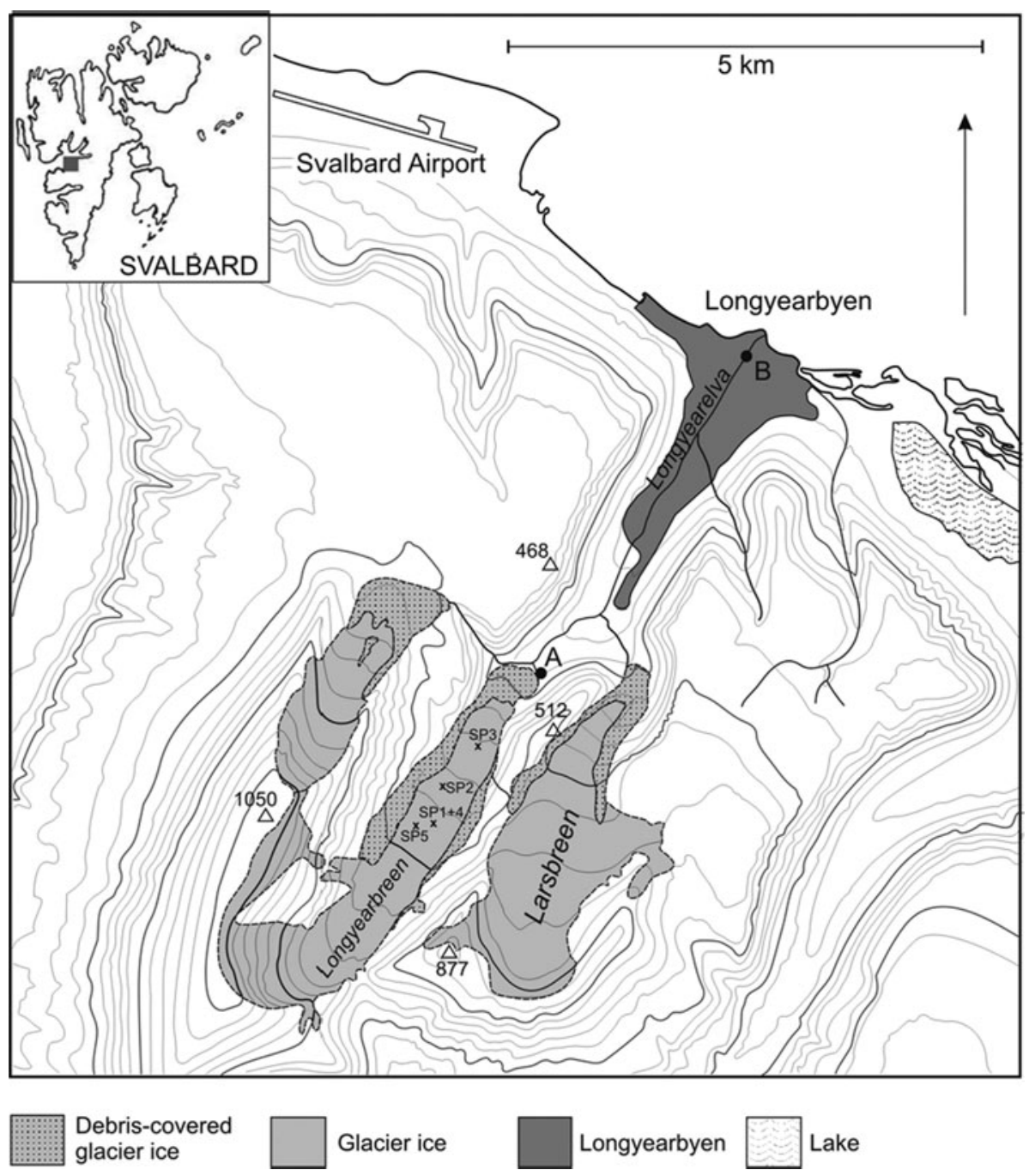

Fig. 1. Location map of Longyearbreen, Svalbard. Site A denotes the sampling site, and site B is the location of the hydrometric station. The locations of excavated snow pits (SP1 to SP5) are marked by crosses.

\section{STUDY AREA}

Longyearbreen $\left(78^{\circ} 11^{\prime} \mathrm{N}, 15^{\circ} 30^{\prime} \mathrm{E}\right)$ is a $4.8 \mathrm{~km}$ long, northeast-oriented valley glacier located in central Spitsbergen, Svalbard (Fig. 1). It has an altitude range of $210-850 \mathrm{~m}$ a.s.I. and the equilibrium-line altitude (ELA) is at $\sim 615 \mathrm{~m}$ a.s.I. (Bringedal, 2004). Its average thickness is $53 \mathrm{~m}$, and the velocity at the ELA is $\sim 2-4 \mathrm{~m} \mathrm{a}^{-1}$ (Etzelmüller and others, 2000). The topographic catchment area of bulk meltwater emanating from Longyearbreen covers $10.7 \mathrm{~km}^{2}$ of which $43 \%$ is glacierized, and includes parts of Larsbreen and an unnamed glacier coded [14203] in the regional glacier inventory of Svalbard (Hagen and others, 1993). As the englacial routings of the drainage systems of these two glaciers are unknown, the hydrological catchment area may deviate from the topographic.

At Svalbard Airport, $6 \mathrm{~km}$ northwest of Longyearbreen, the mean annual air temperature is $-5.8^{\circ} \mathrm{C}(1975-2000)$, and the uncorrected annual precipitation has been measured as $\sim 190 \mathrm{~mm}$ w.e. (Førland and others, 1997; Humlum, 2002). The study area is located within the continuous permafrost zone.

Longyearbreen shows no signs of surge activity. The lower part of the glacier is debris-covered, and lateral moraines border the glacier to the ELA. Investigations within accessible meltwater conduits during the winter reveal undisturbed vegetation at the glacier-bed interface, a temperature of $-4^{\circ} \mathrm{C}$ at the glacier bed and no indications of significant basal deformation or abrasion (Humlum and others, 2005). Permafrost in central Spitsbergen is $100-500 \mathrm{~m}$ thick (Humlum and others, 2003) and extends below several glaciers as is known from mining operations (Liestøl, 1977; Christiansen and others, 2005). The subglacial permafrost at Longyearbreen (Humlum and others, 2005) is therefore likely to be continuous with permafrost beyond the glacier. Tonning (1996) and Etzelmüller and others (2000) interpreted weak radio-echo reflections as indicating that temperate ice existed beneath the upper western area of Longyearbreen. This is in contrast to what is known about permafrost thickness in the area and to interpretations of new radio-echo soundings by Riger-Kusk (2006), which indicate that Longyearbreen is entirely cold-based and that the weak reflectors are caused by frozen debris-rich basal ice.

The englacial drainage system forms by incision of supraglacial streams. At a depth of 8-12 $\mathrm{m}$ the roofs of the channels close by ice deformation (Humlum and others, 2005). As long as the conduits remain connected to the drainage network, they continue a three-dimensional meandering towards the glacier bed. If the water supply to an englacial conduit terminates, ice deformation closes the 
conduit and any sediment deposits at the conduit floor form a sorted debris band. These sediments can later be remobilized by englacial erosion by adjacent conduits. At the glacier bed, meltwater erosion extends further into subglacial permafrozen talus sheets (Humlum and others, 2005), which constitute a significant part of the glacier-bed interface along the lateral margins. There are no naled assemblages in front of Longyearbreen, indicating that winter runoff is negligible.

The geology is composed of the Palaeocene Firkanten and Basilika Formations, and the Eocene-Miocene Sarkofagen, Gilsonryggen, Battfjellet and Aspelintoppen Formations (Major and Nagy, 1972). These formations mainly consist of shales, siltstones and sandstones with contents of coal seams, chert nodules, volcanic tuffs and clay-ironstones (Major and Nagy, 1972). The lowermost Firkanten Formation is commercially the most important coal-bearing formation on Svalbard, and its Longyear coal seam has been mined near the terminal moraine of Longyearbreen. Although the glacier bed at the terminus is believed to be in contact with Firkanten Formation, the majority of coal debris transported by Longyearbreen is derived from headwall erosion of Aspelintoppen Formation.

\section{SAMPLING AND ANALYTICAL METHODOLOGY}

Snow samples $(n=39)$ were recovered in April 2004 from the walls of five snow pits at altitudes between 355 and $475 \mathrm{~m}$ on Longyearbreen. The samples were collected either in pre-rinsed polypropylene bottles or in polythene bags and then transferred to bottles after thawing. The sampling interval was $0.10 \mathrm{~m}$.

Bulk meltwater samples $(n=183)$ were collected 20$100 \mathrm{~m}$ from the outlet of the eastern meltwater stream from Longyearbreen. The sampling site was chosen as the meltwater outlet was more easily accessible than a western outlet. The eastern stream contributed about $33 \%$ of the total discharge of the Longyearbreen catchment, and the remaining discharge came from the western outlet. The sampling site was relocated within $100 \mathrm{~m}$ of the outlet on several occasions due to changes in access conditions and channel migration. Bulk meltwater drainage commenced on 29 May 2004 and terminated on 11 September 2004 (a total duration of 106 days). Within this period, sampling was conducted at various time increments, but generally with a frequency of 12 or 24 hours (before 9 June and after 9 August at $1200 \mathrm{~h}$ and $2400 \mathrm{~h}$; in the intervening period at $0600 \mathrm{~h}$ and $1800 \mathrm{~h}$ ). On 21/22 June and 28/29 July, diurnal time series were obtained with sampling frequencies of 1 hour. Between the periods 4 to 9 August and 19 August to 6 September no samples were collected. In addition, multisampling $(n=10)$ was conducted at $1800 \mathrm{~h}$ on 16 August in order to elucidate the combined effects of analytical precision and waterquality fluctuations at the sampling site. Samples were collected in $250 \mathrm{~mm}^{3}$ pre-rinsed polypropylene bottles for hydrochemical analyses containing as little air as possible, and in $20 \mathrm{~mm}^{3}$ bottles for $\delta^{18} \mathrm{O}$ analyses. Bottles and lids were rinsed in meltwater prior to sampling, and disposable gloves were used to avoid contamination.

Precipitation was collected directly in pre-rinsed bottles during snow $(n=9)$ and rain $(n=4)$ events at the bulk meltwater sampling site.

All samples were stored in the dark at $4{ }^{\circ} \mathrm{C}$. Filtration was not conducted immediately after sample collection, but
2.5-6 months after sampling. The reasons for this were that it was expected that the dominant geochemical reaction rates in this lithological setting were fast, and that the relatively high suspended sediment concentrations with mean and maximum values of 1.32 and $13.74 \mathrm{~g} \mathrm{~L}^{-1}$, respectively, would make careful field filtration difficult. Thus, overestimation due to post-sampling mineral dissolution is expected and will be discussed later. Filtration was conducted using cellulose nitrate membranes with a retention diameter of $0.45 \mu \mathrm{m}$. The concentrations of major cations $\left(\mathrm{Na}^{+}, \mathrm{K}^{+}, \mathrm{Mg}^{2+}, \mathrm{Ca}^{2+}\right)$, major anions $\left(\mathrm{Cl}^{-}, \mathrm{NO}_{3}{ }^{-}\right.$, $\mathrm{SO}_{4}{ }^{2-}$ ) and dissolved $\mathrm{Si}$ were determined using the methods described in Yde and others (2005). The analytical precisions were $\pm 5 \%$ for $\mathrm{Na}^{+}, \mathrm{Mg}^{2+}, \mathrm{Cl}^{-}, \mathrm{NO}_{3}{ }^{-}$and $\mathrm{SO}_{4}{ }^{2-}$, and $\pm 10 \%$ for $\mathrm{K}^{+}, \mathrm{Ca}^{2+}$ and $\mathrm{Si}$. The analytical precision errors increase as detection limits for the individual ions are approached, which has implications for the precision of the snow chemistry in particular. Alkalinity (primarily $\mathrm{HCO}_{3}{ }^{-}$) was estimated from charge balance. Measurements of conductivity and $\mathrm{pH}$ were conducted in situ at the time of sampling, but suspended sediments and low ionic strength caused some instrumental drift, inflicting low precision for the $\mathrm{pH}$ values of about \pm 0.3 . Stable oxygen isotope analyses were performed at the Niels Bohr Institute, Copenhagen, Denmark, using mass spectrometry with a ratio precision of $\pm 0.04 \%$.

Water discharge was computed from water stage logged at $10 \mathrm{~min}$ intervals at a hydrometric station situated $4 \mathrm{~km}$ down-valley at a bridge in Longyearbyen. Relations for the 1997 runoff season estimated by Grønsten (1998) were applied to convert stage to discharge:

$$
\begin{array}{ll}
Q=200 h^{3.64} & \text { if } h<0.39 m \\
Q=22 h^{1.29} & \text { if } h \geq 0.39 m,
\end{array}
$$

where $Q$ is discharge $\left(\mathrm{m}^{3} \mathrm{~s}^{-1}\right)$ and $h$ is water stage $(\mathrm{m})$. Monitoring of water stage failed between $2230 \mathrm{~h}$ on 25 July and $1000 \mathrm{~h}$ on 3 August, probably as a consequence of water infiltration into the data logger during a period of high discharge. Based on field observations, it is assumed that the Longyearbreen catchment contributes about $50 \%$ of the total discharge at the hydrometric station through the entire runoff season. Although diurnal and seasonal variations of $\pm 20 \%$ may have occurred, no non-climatic outburst events were observed, except for possible storage and release of meltwater in the late melt season. The duration of runoff at the hydrometric station lasted from 5 June to 8 September (a total of 96 days).

\section{RESULTS}

Solute concentrations and oxygen isotope values from five snow pits on Longyearbreen are shown in Table 1 together with the chemical and isotopic characteristics of fresh snow and rainwater collected at the bulk water sampling site at the glacier terminus. Snow pits 1 and 4 were located within a few metres of each other, and snow pit 2 was situated on the main snowmobile track, which runs along the western part of the glacier (Fig. 1). The mean molar $\mathrm{Na}^{+} / \mathrm{Cl}^{-}$and $\mathrm{SO}_{4}{ }^{2-} / \mathrm{Cl}^{-}$ratios were $\sim 0.80 \pm 0.07$ and $0.17 \pm 0.08$, respectively (if the top sample in snow pit 3 was neglected, this snow pit showed a $\mathrm{SO}_{4}{ }^{2-} / \mathrm{Cl}^{-}$ratio of $0.13 \pm 0.07$ ). These ratios can be compared with the $0.56 \mathrm{Na}^{+} / \mathrm{Cl}^{-}$ratio and $0.14 \mathrm{SO}_{4}{ }^{2-} / \mathrm{Cl}^{-}$ratio found in sea water (Holland, 1978), 


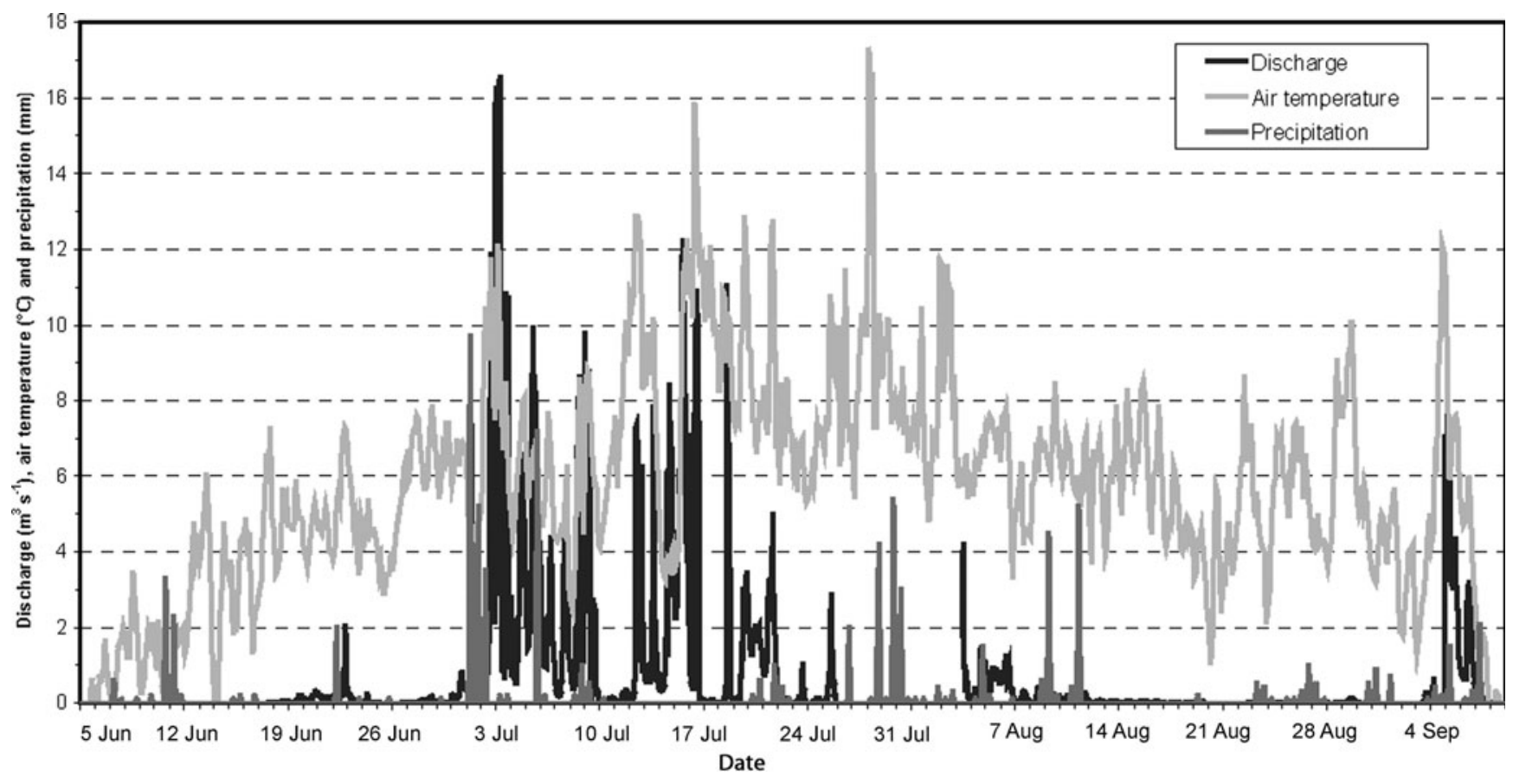

Fig. 2. Time series of discharge measured at site B, and air temperature and precipitation measured at Svalbard Airport between 5 June and 8 September 2004. Discharge measurements are missing between 25 July and 3 August 2004.

indicating that addition of solutes from provenances other than sea water has occurred. Pollution from snowmobiles or enhanced deposition of acid aerosols due to coal combustion in Longyearbyen could not be detected in the snow chemistry. Relatively high concentrations of $\mathrm{Ca}^{2+}$ and $\mathrm{SO}_{4}{ }^{2-}$ in fresh snow and rainwater indicate transport and deposition of dust during precipitation events.

The hydrograph and time series of air temperature and precipitation are presented in Figure 2. During the early melt season (29 May to 30 June 2004) discharge was low and only a single precipitation event on 22/23 June, followed by increased air temperatures, caused slightly increased discharge. A major rainfall event on 1 July followed by clear sky and strong winds caused rapid collapse of the snowpack and marked the transition to the peak-flow period (1 July to 6 August 2004). During this period, discharge was primarily related to variations in air temperature and secondarily to episodic rainfall. Between 25 July and 3 August, when the data logger failed to record water stage, the highest discharges were visually observed to occur. The late melt season (7 August to 11 September 2004) was characterized by decreasing air temperature, passage of low-pressure weather systems and low discharge. An event of relatively high air temperatures on 28/29 August had no significant effect on discharge, whereas a similar event on 4/5 September caused a marked increase in runoff. This difference could be due to a combination of snowmelt at high altitudes and reopening of dammed parts of the subglacial drainage system resulting in subsequent release of stored water.

The annual discharge of 2004 was estimated as $3.66 \pm 0.73 \times 10^{6} \mathrm{~m}^{3}$, equivalent to a specific discharge of $0.34 \pm 0.07 \mathrm{~m}$, and the discharge distribution between the early melt season, the peak-flow period and the late melt season was $1.7 \%, 89.7 \%$ and $8.6 \%$, respectively. Uncorrected rainfall during the ablation season (29 May to 11 September 2004) constituted 23\% of the total runoff.
The $\delta^{18} \mathrm{O}$ time series and chemographs are shown in Figure 3 and described in relation to the hydrological periods outlined above. A statistical summary of the major-ion concentrations and $\delta^{18} \mathrm{O}$ composition is presented in Table 2 .

\section{Early melt season}

This period was characterized by large variations in solute concentrations, which superimpose any diurnal fluctuations. The $\delta^{18} \mathrm{O}$ values (Fig. 3a) varied from $-16.7 \%$ in the initial meltwater runoff to about $-14.5 \%$ at the end of the period. The ice-melt level of about $-13.5 \%$ was not reached until 3 July. The initial low $\delta^{18} \mathrm{O}$ values were in accordance with the $\delta^{18} \mathrm{O}$ values measured in the snow pits (Table 1 ), and the fluctuations were most probably linked to variations in the relative proportions of snowmelt and ice melt (Yde and Knudsen, 2004), where ice melt could be derived from both glacier ice and thawing of the periglacial active layer. The enrichment of heavy oxygen isotopes observed on 22/ 23 June coincided with a rainfall event. The diurnal variations of ion strength and $\delta^{18} \mathrm{O}$ on $21 / 22$ June (Fig. 4a) show that the increase in $\delta^{18} \mathrm{O}$ caused by precipitation coincided with dilution of ion concentrations. All major solutes fluctuated in relation to each other (Fig. 3b-h). However, in the case of $\mathrm{Cl}^{-}$the fluctuations were superimposed upon a general decline in concentration (Fig. 3b). Also, the fluctuations in solute concentrations did not coincide with the fluctuations measured for $\delta^{18} \mathrm{O}$. The $\mathrm{pH}$ values ranged between 7.0 and 7.7 , and conductivities ranged between 70 and $420 \mu \mathrm{S} \mathrm{cm}^{-1}$.

\section{Peak-flow period}

The $\delta^{18} \mathrm{O}$ values had a base level of about $-13.5 \%$ (Fig. 3a). The effect of the 1 July precipitation event (Fig. 2) on isotopic fluctuations was masked by the subsequent transition from primarily snowmelt to glacier ice melt. However, a second rainfall event, which occurred on 28/29 July, is 


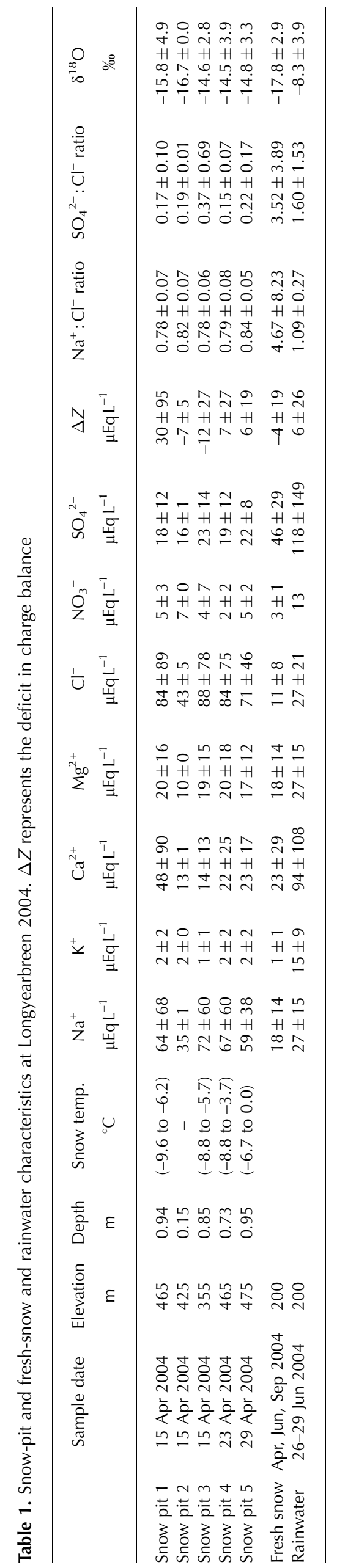

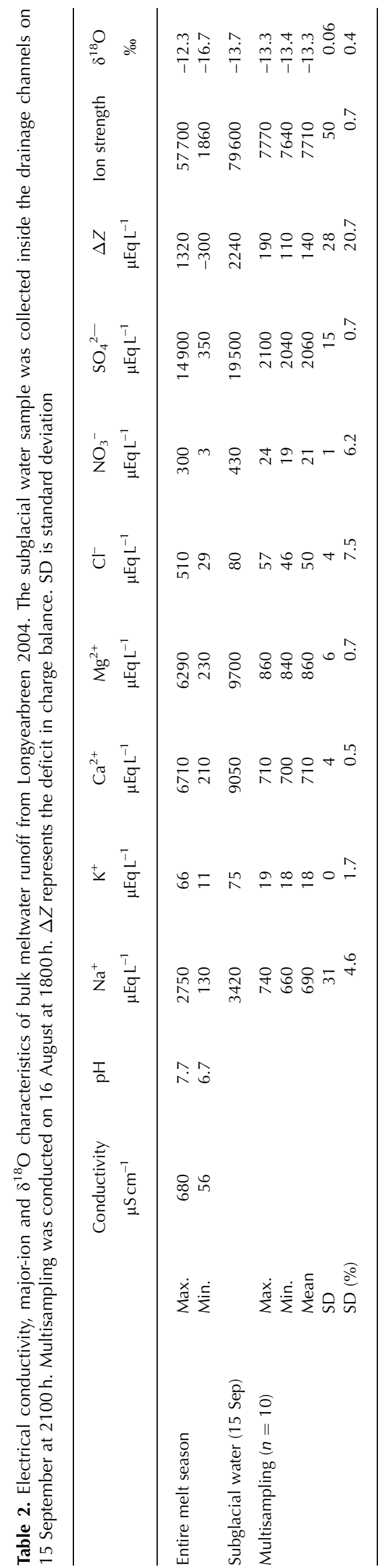



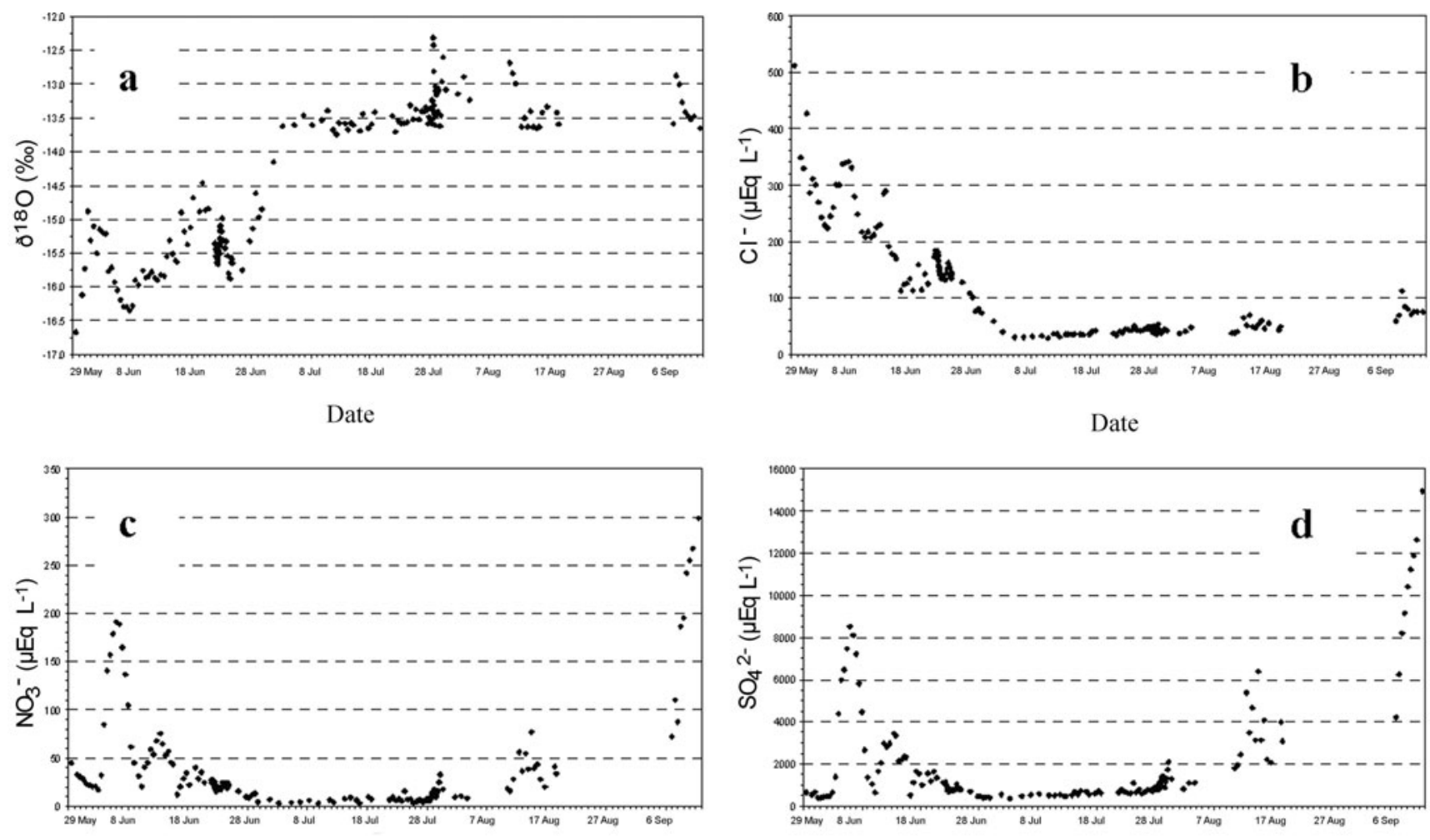

Date
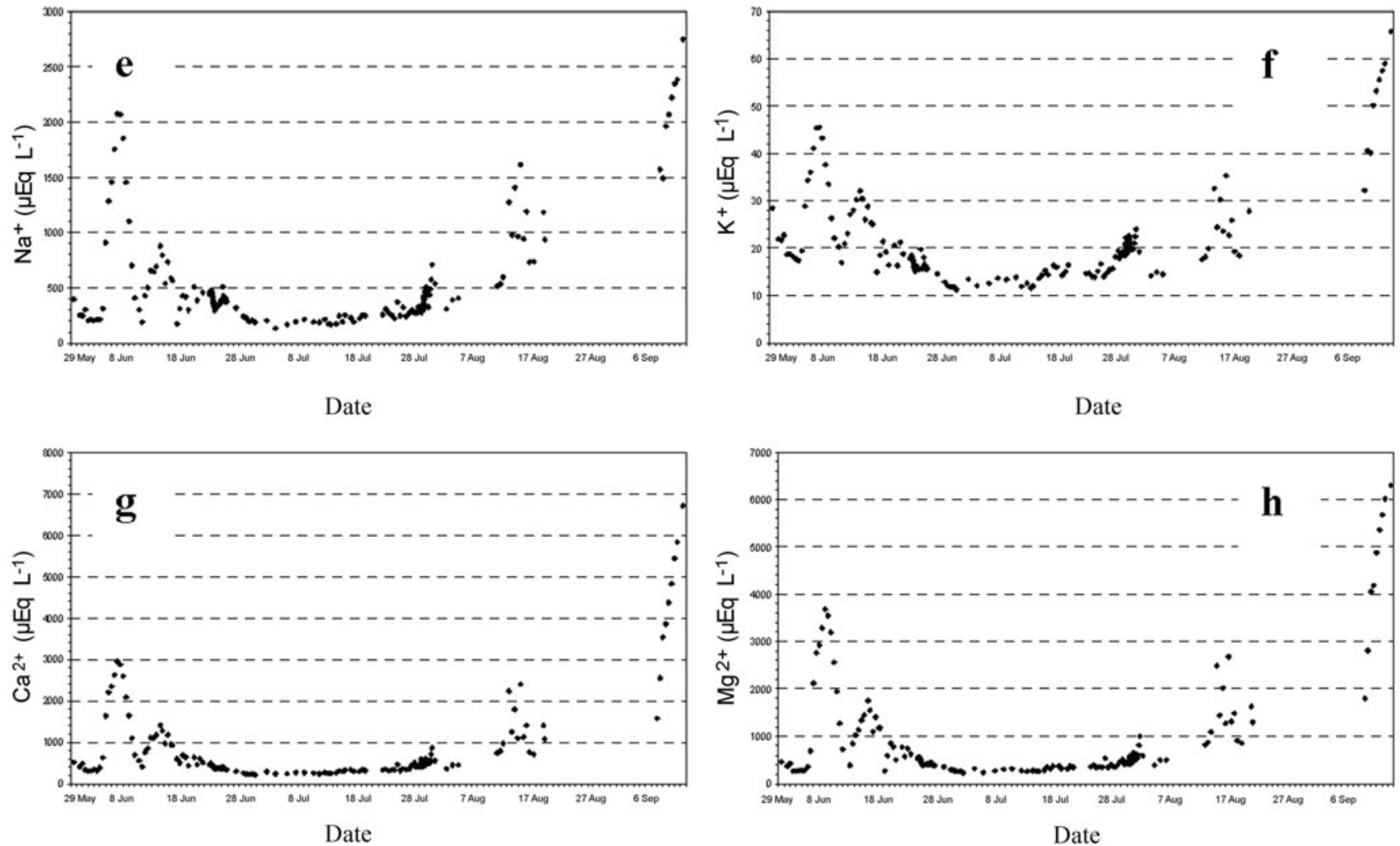

Fig. 3. Time series of (a) measured $\delta^{18} \mathrm{O}$ values and (b-h) major anion and cation concentrations, Longyearbreen, 2004. (b) $\mathrm{Cl}^{-}$, (c) $\mathrm{NO}_{3}{ }^{-}$, (d) $\mathrm{SO}_{4}{ }^{2-}$, (e) $\mathrm{Na}^{+}$, (f) $\mathrm{K}^{+}$, (g) $\mathrm{Ca}^{2+}$ and (h) $\mathrm{Mg}^{2+}$.

easily recognizable in the $\delta^{18} \mathrm{O}$ values (Fig. 4b). When the rainfall was most intense, the isotopic effect was most pronounced. Solute concentrations (Fig. 3b-h) increased slightly throughout July, and diurnal variations due to dilution by alternating flow components were almost negligible. On
28 July a rapid increase in solute concentrations occurred, which culminated at $0600 \mathrm{~h}$ on 30 July. The $\mathrm{pH}$ values were $6.8-7.7$, and the conductivities were $70-120 \mu \mathrm{S} \mathrm{cm}^{-1}$ until 28 July when the conductivity increased and peaked at $0600 \mathrm{~h}$ on 30 July, at $270 \mu \mathrm{S} \mathrm{cm}^{-1}$. 

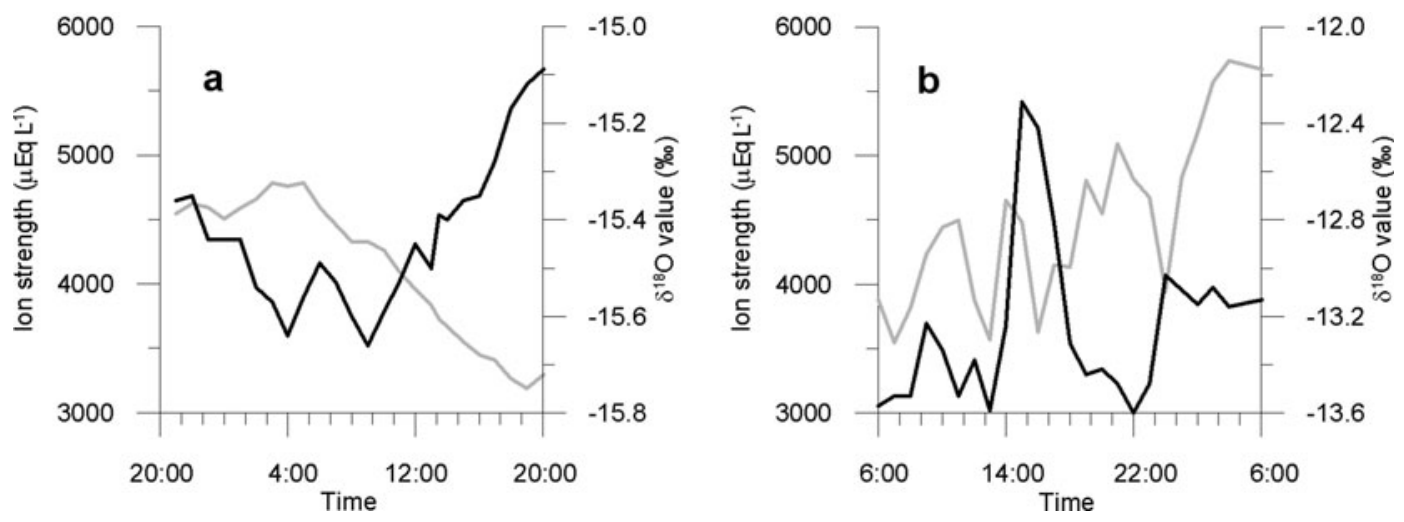

Fig. 4. Diurnal ion strength (grey curve) and $\delta^{18} \mathrm{O}$ values (black curve): (a) 21/22 June 2004 and (b) 28/29 July 2004.

\section{Late melt season}

During this period the $\delta^{18} \mathrm{O}$ values deviated from the base $\left(-13.5 \%\right.$ ) level by periods of high $\delta^{18} \mathrm{O}$ values in association with heavy rainfall events such as on 10/11 August and 6/7 September (Fig. 3a). The solute concentrations were generally much higher than in the peak-flow period, and the relation to discharge was stronger and, hence, the diurnal dilution effect was more pronounced. Unfortunately, no sampling was conducted during the late warm period on $4 / 5$ September, so the effect of the drastic increase in discharge on the hydrochemistry is unknown. The $\mathrm{pH}$ was not measured during this period. Conductivities were relatively high, ranging between 230 and $680 \mu \mathrm{sm}^{-1}$. On 15 September 2004, when runoff had ceased at the glacier terminus, the subglacial drainage system was accessible several hundred meters below the glacier. Water was still gently flowing inside the subglacial drainage system, and a single water sample collected within the subglacial drainage channels showed a $\delta^{18} \mathrm{O}$ value of $-13.7 \%$, a sum of dissolved cations of $22240 \mathrm{\Sigma \mu Eq}^{+} \mathrm{L}^{-1}$ and the highest measured concentrations of all major ions except $\mathrm{Cl}^{-}$ (Table 2).

\section{Multisampling}

Multisampling characteristics are presented in Table 2. The combined effect of bulk water mixing at the sampling site and analytical precision is represented by the standard deviation (SD) in percent, which showed acceptable deviations for all major ions, although the SD of the calculated charge balance $(\Delta Z)$ deviated by more than $20 \%$.

Table 3. Water composition variations in bulk meltwater runoff from Longyearbreen 2004

\begin{tabular}{llll}
\hline Period & Chemical composition & From & To \\
\hline \multirow{2}{*}{ Early melt season } & $\mathrm{SO}_{4}{ }^{2-} \mathrm{Cl}^{-} \mathrm{Ca}^{2+} \mathrm{Na}^{+}$ & 29 May & 02 Jun \\
& $\mathrm{SO}_{4}{ }^{2-} \mathrm{Ca}^{2+} \mathrm{Mg}^{2+} \mathrm{Na}^{+}$ & 03 Jun & 04 Jun \\
& $\mathrm{SO}_{4}{ }^{2-} \mathrm{Ca}^{2+} \mathrm{Na}^{+} \mathrm{Mg}^{2+}$ & 05 Jun & $11 \mathrm{Jun}$ \\
& $\mathrm{SO}_{4}{ }^{2-} \mathrm{Ca}^{2+} \mathrm{Mg}^{2+} \mathrm{Na}^{+}$ & 12 Jun & $20 \mathrm{Jun}$ \\
Peak-flow period & $\mathrm{SO}_{4}{ }^{2-} \mathrm{HCO}_{3}{ }^{-} \mathrm{Na}^{+} \mathrm{Ca}^{2+}$ & 21 Jun & $30 \mathrm{Jun}$ \\
Late melt season & $\mathrm{SO}_{4}{ }^{2-} \mathrm{HCO}_{3} \mathrm{Ca}^{2+} \mathrm{Na}^{+}$ & 01 Jul & 03 Aug \\
& $\mathrm{SO}_{4}{ }^{2-} \mathrm{Ca}^{2+} \mathrm{Na}^{+} \mathrm{Mg}^{2+}$ & 10 Aug & $18 \mathrm{Aug}$ \\
& $\mathrm{SO}_{4}{ }^{2-} \mathrm{Ca}^{2+} \mathrm{Mg}^{2+} \mathrm{Na}^{+}$ & 07 Sep & $11 \mathrm{Sep}$ \\
\hline
\end{tabular}

\section{Water composition}

The water composition varied throughout the season, with $\mathrm{SO}_{4}{ }^{2-}$ being the most important ion (Table 3 ). $\mathrm{Cl}^{-}$was only measured in significant concentrations at the very beginning of the early melt season. $\mathrm{Ca}^{2+}, \mathrm{Mg}^{2+}$ and $\mathrm{Na}^{+}$were important during most of the early melt season and again during the late melt season, while $\mathrm{HCO}_{3}{ }^{-}$, estimated as the $\Delta Z$, was significant during the end of the early melt season and throughout the peak-flow period at the expense of $\mathrm{Mg}^{2+}$.

The relationships between the concentrations of individual ions and $\delta^{18} \mathrm{O}$ values are shown in Table 4. Strong statistical associations existed between $\mathrm{Na}^{+}, \mathrm{K}^{+}, \mathrm{Ca}^{2+}$, $\mathrm{Mg}^{2+}, \mathrm{NO}_{3}{ }^{-}$and $\mathrm{SO}_{4}{ }^{2-}$, whereas $\mathrm{Cl}^{-}$and ${ }^{18} \delta^{18} \mathrm{O}$ were inversely correlated. For other solutes, $\mathrm{Cl}^{-}$is best associated with $\mathrm{NO}_{3}{ }^{-}$.

\section{Annual solute flux estimation}

Annual solute fluxes in glacierized catchments have been calculated from either best-fit regression equations of measured solute concentrations to logged mean discharge measurements (e.g. Lemmens, 1978; Lemmens and Roger, 1978; Souchez and Lemmens, 1987; Sharp and others, 1995; Hodgkins and others, 1997; Yde and others, 2005) or the product of discharge-weighted-mean solute concentrations and discharge (e.g. Wadham and others, 1997; Hodson and others, 2000, 2002; Krawczyk and others, 2003; Hosein and others, 2004). Logistic and economic factors often limit field sampling to a defined time interval during the peak-flow period. Our dataset provides the sampling distribution throughout an entire ablation season

Table 4. Correlation coefficients (upper right) and $p$ values (lower left) of major ions and $\delta^{18} \mathrm{O}$ at Longyearbreen 2004. Negative values indicate inverse correlation

\begin{tabular}{lcccccccc}
\hline & $\mathrm{Na}^{+}$ & $\mathrm{K}^{+}$ & $\mathrm{Ca}^{2+}$ & $\mathrm{Mg}^{2+}$ & $\mathrm{Cl}^{-}$ & $\mathrm{NO}_{3}{ }^{-}$ & $\mathrm{SO}_{4}{ }^{2-}$ & $\delta^{18} \mathrm{O}$ \\
\hline $\mathrm{Na}^{+}$ & - & 0.95 & 0.95 & 0.97 & 0.18 & 0.94 & 0.98 & -0.03 \\
$\mathrm{~K}^{+}$ & $<0.01$ & - & 0.96 & 0.96 & 0.25 & 0.95 & 0.96 & -0.04 \\
$\mathrm{Ca}^{2+}$ & $<0.01$ & $<0.01$ & - & 0.99 & 0.11 & 0.95 & 0.99 & 0.04 \\
$\mathrm{Mg}^{2+}$ & $<0.01$ & $<0.01$ & $<0.01$ & - & 0.15 & 0.96 & 1.00 & 0.01 \\
$\mathrm{Cl}^{-}$ & 0.02 & $<0.01$ & 0.13 & 0.05 & - & 0.31 & 0.14 & -0.85 \\
$\mathrm{NO}_{3}{ }^{-}$ & $<0.01$ & $<0.01$ & $<0.01$ & $<0.01$ & $<0.01$ & - & 0.96 & -0.17 \\
$\mathrm{SO}_{4}{ }^{2-}$ & $<0.01$ & $<0.01$ & $<0.01$ & $<0.01$ & 0.06 & $<0.01$ & - & 0.01 \\
$\delta^{18} \mathrm{O}^{2}$ & 0.69 & 0.63 & 0.59 & 0.94 & $<0.01$ & 0.03 & 0.88 & - \\
& & & & & & & & \\
\hline
\end{tabular}


Table 5. Deviation in percent between measured and estimated ion concentrations at Longyearbreen 2004 for three different regression models

\begin{tabular}{|c|c|c|c|c|c|c|c|c|c|}
\hline Method & Period & $\mathrm{Na}^{+}$ & $\mathrm{K}^{+}$ & $\mathrm{Ca}^{2+}$ & $\mathrm{Mg}^{2+}$ & $\mathrm{Cl}^{-}$ & $\mathrm{NO}_{3}^{-}$ & $\mathrm{SO}_{4}{ }^{2-}$ & $\mathrm{HCO}_{3}{ }^{-}$ \\
\hline \multicolumn{10}{|c|}{ All-sample regression (method 1 ) } \\
\hline Early melt season & 5 Jun to 30 Jun & 15 & 6 & 22 & 23 & -29 & 4 & 24 & 15 \\
\hline Peak-flow period & 1 Jul to 6 Aug & 55 & 17 & 45 & 48 & 110 & 189 & 55 & -4 \\
\hline Late melt season & 7 Aug to 8 Sep & -57 & -30 & -59 & -59 & 82 & -46 & -67 & -11 \\
\hline \multicolumn{10}{|c|}{ Peak-flow regression (method 2) } \\
\hline Early melt season & 5 Jun to 30 Jun & -39 & -23 & -34 & -35 & -74 & -71 & -36 & 26 \\
\hline Peak-flow period & 1 Jul to 6 Aug & 0 & 0 & 0 & 0 & 0 & 6 & 0 & 1 \\
\hline Late melt season & 7 Aug to 8 Sep & -75 & -46 & -76 & -77 & -26 & -83 & -82 & -3 \\
\hline \multicolumn{10}{|c|}{ Interval regression (method 3) } \\
\hline Early melt season & 5 Jun to 30 Jun & 8 & 2 & 7 & 8 & 3 & 13 & 11 & 5 \\
\hline Peak-flow period & 1 Jul to 6 Aug & 0 & 0 & 0 & 0 & 0 & 6 & 0 & 1 \\
\hline Late melt season & 7 Aug to 8 Sep & 2 & -1 & 2 & 1 & 0 & 2 & 1 & 6 \\
\hline
\end{tabular}

that is required to elucidate the errors involved in applying extrapolations and to compare the use of regression and discharge-weighted-mean concentration methods.

Table 5 shows the percentile deviations between measured and estimated ion concentrations for three different best-fit regression procedures: (method 1) if all measurements are used with no corrections for sampling frequency or seasonal hydrological and hydrochemical effects, solute fluxes during the early melt season and the peak-flow period are significantly overestimated, whereas solute fluxes during the late melt season are significantly underestimated. The exception to this is $\mathrm{Cl}^{-}$, which is underestimated during the early melt season and overestimated during the late melt season; (method 2) if regression equations are based on samples collected during the peak-flow period (in this case, samples collected between 1 and 25 July 2004) and extrapolation is conducted over the remaining ablation season, a significant underestimation of both the early and late melt seasons is observed. The deviations from 0 during the peak-flow period in Table 5 are due to the extrapolation of the period 1-25 July 2007 over the entire peak-flow period; (method 3) if separate regressions are developed for each seasonal interval, an acceptable association between measured and estimated solute concentrations during the entire ablation season is obtained; the late melt season was divided into two sub-intervals in order to improve the deviations, but splitting the early melt season into subintervals did not improve the deviations.

Correlation coefficients between discharge and major-ion concentrations for the all-sample regression (method 1 ) and for each interval regression (method 3) are presented in Table 6. Bicarbonate concentrations showed no correlation with discharge in any of the regressions, and the correlation of $\mathrm{K}^{+}$to discharge during the peak-flow period was not statistically significant. Also, the correlations of $\mathrm{Na}^{+}, \mathrm{Ca}^{2+}$, $\mathrm{Mg}^{2+}, \mathrm{Cl}^{-}$and $\mathrm{NO}_{3}{ }^{-}$to discharge during the late melt season were not statistically significant due to the relatively limited number of water samples.

Table 7 shows the different solute fluxes computed using the three regression methods outlined above, and solute fluxes estimated by discharge-weighted-mean concentrations of all samples (method 4), by seasonal discharge-weightedmean concentrations (method 5) and by extrapolation of peak-flow discharge-weighted-mean concentrations to the early and late melt seasons (method 6). For the period 25 July to 3 August 2004, discharge was estimated based upon field observations and comparisons with days with similar water levels. The uncertainty associated with this discharge estimation is believed to be approximately $\pm 10 \%$. The extrapolation of peak-flow period regression equations to the early and late melt season (method 2) provided the lowest annual solute fluxes of the regression models, whereas the all-sample regression method (method 1) showed relatively high $\mathrm{Na}^{+}, \mathrm{Cl}^{-}$and $\mathrm{NO}_{3}{ }^{-}$fluxes. About $2 \%$ of the solutes were evacuated during the early melt season in all three regression models, but the interval regression method (method 3 ) showed that $16 \%$ of the solute flux occurred during the late melt season, whilst the two other regression methods only showed effluxes of $\sim 8 \%$.

Table 6. Correlation coefficients between discharge and major-ion concentrations for the annual all-sample regression model and the interval regression model. The correlation coefficients for the two sub-intervals in the late melt season are separated by a slash

\begin{tabular}{|c|c|c|c|c|c|c|c|c|c|}
\hline Method & Period & $\mathrm{Na}^{+}$ & $\mathrm{K}^{+}$ & $\mathrm{Ca}^{2+}$ & $\mathrm{Mg}^{2+}$ & $\mathrm{Cl}^{-}$ & $\mathrm{NO}_{3}^{-}$ & $\mathrm{SO}_{4}{ }^{2-}$ & $\mathrm{HCO}_{3}^{-}$ \\
\hline $\begin{array}{l}\text { All-sample regression (method } 1) \\
\text { Annual }\end{array}$ & 5 Jun to 8 Sep & 0.59 & 0.65 & 0.63 & 0.64 & 0.55 & 0.67 & 0.62 & 0.13 \\
\hline $\begin{array}{l}\text { Interval regression (method } 3 \text { ) } \\
\text { Early melt season } \\
\text { Peak-flow period } \\
\text { Late melt season }\end{array}$ & $\begin{array}{l}5 \text { Jun to } 30 \text { Jun } \\
1 \text { Jul to } 6 \text { Aug } \\
7 \text { Aug to } 8 \text { Sep }\end{array}$ & $\begin{array}{c}0.72 \\
0.48 \\
0.67 / 0.70\end{array}$ & $\begin{array}{c}0.82 \\
0.12 \\
0.54 / 0.92\end{array}$ & $\begin{array}{c}0.83 \\
0.39 \\
0.39 / 0.99\end{array}$ & $\begin{array}{c}0.82 \\
0.44 \\
0.44 / 0.99\end{array}$ & $\begin{array}{c}0.64 \\
0.52 \\
0.35 / 0.74\end{array}$ & $\begin{array}{c}0.78 \\
0.48 \\
0.55 / 0.80\end{array}$ & $\begin{array}{c}0.80 \\
0.47 \\
0.52 / 0.99\end{array}$ & $\begin{array}{c}0.23 \\
0.02 \\
0.18 / 0.75\end{array}$ \\
\hline
\end{tabular}


Table 7. Solute fluxes (kg) in bulk meltwater runoff at Longyearbreen 2004 estimated by three regression models and three dischargeweighted-mean ion concentration models

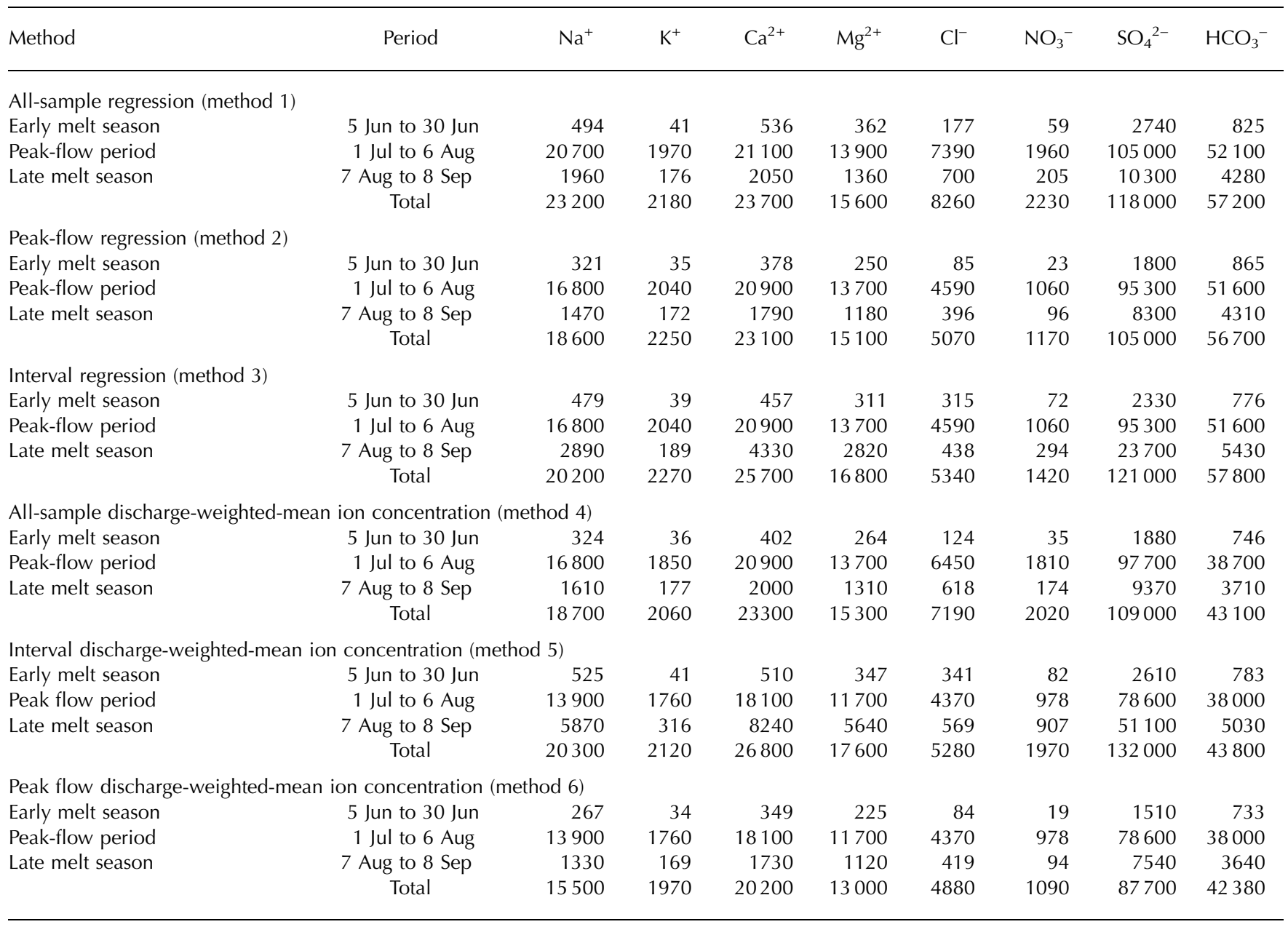

The discharge-weighted-mean concentration method using all samples (method 4) is sensitive to the number of samples collected each season and to the occurrence of discharge events. In this study, this method seemed to underestimate the annual mean ion concentrations compared to what is known from the measured ion concentrations and the distribution of discharge. When the interval discharge-weighted-mean concentrations are used to calculate solute fluxes (method 5), the mean ion concentrations are significantly underestimated for the peak-flow period because discharge weighting makes the relatively dilute ion concentrations at the beginning of the peak-flow period more important than the slightly enriched ion concentrations in the end of the period. Conversely the mean ion concentrations are significantly overestimated for the late melt season because sampling primarily occurred in periods with high solute concentrations. If the discharge-weightedmean concentration for the peak-flow period is used for extrapolation to the early and late melt seasons (method 6), all intervals are significantly underestimated as a consequence of the underestimation of the peak-flow-period solute concentrations.

A more accurate method is to apply the products of daily discharge-weighted-mean ion concentrations and daily discharge, which are subsequently summed to determine the annual solute fluxes. This method requires a sampling strategy with at least daily sample collection at minimum and maximum discharge and an unbroken discharge record. Also, discharge events such as precipitation or outburst events may require additional sampling.

In addition to the best-fit regression and dischargeweighted-mean concentration models, annual solute fluxes can be estimated by linear interpolation between successive solute concentrations multiplied by discharge. This method has the advantages that it is very sensitive and not directly related to discharge, but it cannot be used to estimate annual solute fluxes by extrapolation, and if interpolations cover more than a few days it potentially introduces significant errors. Therefore, this method has not found much use in glacier hydrochemistry studies. In this study, the linearinterpolation method significantly underestimated solute concentrations during the period when the data logger failed to record water level, whereas it significantly overestimated during the late melt season when water sampling was not conducted. Hence, it is not possible to compare the application of this method with other methods using the dataset obtained in this study. As for the daily dischargeweighted-mean ion concentration method, the linear interpolation method is believed to be most useful when water samples are collected at minimum and maximum discharge each day and hourly mean discharge is available throughout the entire ablation season. If these conditions are met, linear interpolation is a very accurate method to estimate annual solute fluxes. 
Table 8. Solute provenance in bulk meltwater runoff from Longyearbreen 2004

\begin{tabular}{lrrrr}
\hline Species & $\begin{array}{c}\text { Solute fluxes } \\
\mathrm{kg} \mathrm{km}^{-2}\end{array}$ & $\begin{array}{c}\text { Marine } \\
\mathrm{kg} \mathrm{km}^{-2}\end{array}$ & $\begin{array}{c}\text { Aerosol } \\
\mathrm{kg} \mathrm{km}^{-2}\end{array}$ & $\begin{array}{c}\text { Crustal/organic } \\
\mathrm{kg} \mathrm{km}^{-2}\end{array}$ \\
\hline $\mathrm{Na}^{+}$ & 1890 & 278 & & 1610 \\
$\mathrm{~K}^{+}$ & 212 & 10 & & 202 \\
$\mathrm{Ca}^{2+}$ & 2410 & 11 & & 2400 \\
$\mathrm{Mg}^{2+}$ & 1580 & 33 & & 1540 \\
$\mathrm{Cl}^{-}$ & 500 & 500 & 64 & 69 \\
$\mathrm{NO}_{3}{ }^{-}$ & 133 & & 98 & 11200 \\
$\mathrm{SO}_{4}{ }^{2-}$ & 11400 & 70 & 98 & \\
$\mathrm{HCO}_{3}{ }^{-}$ & 5410 & & & 5410 \\
\hline
\end{tabular}

In the following, annual solute fluxes calculated by interval regression (method 3) are used, as this method provided the most reliable estimates.

\section{Solute provenance}

The origin of solute fluxes was separated into marine, aerosol and crustal/organic provenances. At Longyearbreen, the organic component comprised primarily old organic matter associated with coal seams and, secondarily, newer organic matter such as glacier-covered vegetation. The principle of constant proportions of major ions to $\mathrm{Cl}^{-}$in sea water was applied to distinguish solutes derived from a marine provenance by assuming that no other sources of $\mathrm{Cl}^{-}$ were influential (Holland, 1978). The proportion of $\mathrm{NO}_{3}{ }^{-}$ derived as acid aerosols was computed by assuming an annual concentration of $3 \mu \mathrm{EqL}^{-1}$, equal to the concentration found in fresh snow (Table 1). This is probably an underestimate of the aerosol-derived $\mathrm{NO}_{3}{ }^{-}$input because rainfall events augment deposition of acid aerosols. The aerosol-derived $\mathrm{SO}_{4}{ }^{2-}$ component was computed by assuming that all non-sea-salt-derived $\mathrm{SO}_{4}{ }^{2-}$ in the snowpack originated from acid aerosols. However, this procedure overestimated the aerosol-derived $\mathrm{SO}_{4}{ }^{2-}$ proportion, as it was previously shown by the molar $\mathrm{Na}^{+} / \mathrm{Cl}^{-}$ratio that the snowpack also contained solutes derived from crustal and organic sources. The residual $\mathrm{Na}^{+}, \mathrm{K}^{+}, \mathrm{Ca}^{2+}, \mathrm{Mg}^{2+}, \mathrm{NO}_{3}{ }^{-}$ and $\mathrm{SO}_{4}{ }^{2-}$ fluxes were derived from crustal and organic sources. The $\mathrm{HCO}_{3}{ }^{-}$flux was not separated into provenances as has been done in some previous studies (Sharp and others, 1995; Hodgkins and others, 1997; Hodson and others, 2000, 2002; Krawczyk and others, 2003), due to geochemical factors, which will be discussed later.

Annual solute flux estimates computed by interval regression (method 3) were applied to calculate the specific fluxes shown in Table 8 . About $3.8 \%$ of the solutes derived from sea salts and $0.7 \%$ from acid aerosols. As $\left({ }^{*} \mathrm{Ca}^{2+}+\right.$ ${ }^{*} \mathrm{Mg}^{2+}$ ) accounted for $73 \%$ of the equivalent cationic content and $\mathrm{HCO}_{3}{ }^{-}$accounted for only $26 \%$ of the equivalent anionic content, the $\left({ }^{*} \mathrm{Ca}^{2+}+{ }^{*} \mathrm{Mg}^{2+}\right) / \mathrm{HCO}_{3}{ }^{-}$ ratio of 2.8 was well above unity, indicating that carbonate weathering could easily account for the total $\mathrm{HCO}_{3}{ }^{-}$content (asterisks indicate crustal/organic-derived solutes). The excess $\left({ }^{*} \mathrm{Ca}^{2+}+{ }^{*} \mathrm{Mg}^{2+}\right)$ and $\left({ }^{*} \mathrm{Na}^{+}+{ }^{*} \mathrm{~K}^{+}\right)$was balanced by ${ }^{*} \mathrm{SO}_{4}{ }^{2-}$, which accounted for $68 \%$ of the equivalent anionic content. Hence, it is most likely that as much as $95.5 \%$ of the total solute yield was derived from a crustal/organic provenance. Thus, the crustal/organic-derived proportion is
Table 9. Chemical weathering characteristics of the Longyearbreen catchment in 2004

\begin{tabular}{llr} 
Sum of dissolved cations $\left(\Sigma \mu \mathrm{Eq}^{+} \mathrm{L}^{-1}\right)$ & $\begin{array}{l}\text { Early melt season } \\
\text { Peak-flow period }\end{array}$ & 1111 \\
& Late melt season & 1839 \\
& Annual & 986 \\
& 322 \\
Cation-equivalent weathering rate $\left(\Sigma \mathrm{mEq}^{+} \mathrm{m}^{-2} \mathrm{a}^{-1}\right)$ & 940 \\
Chemical weathering intensity $(\mathrm{CWI})\left(\Sigma \mathrm{mEq}^{+} \mathrm{m}^{-3}\right)$ & $17-22$ \\
Crustal solute yield $\left(\mathrm{t} \mathrm{km}^{-2} \mathrm{a}^{-1}\right)$ & \\
\hline
\end{tabular}

significantly higher than the previous global range of 2883\% for glacierized catchments (Sharp and others, 1995; Hodgkins and others, 1997; Hodson and others, 2000, 2002; Yde and others, 2005).

\section{Chemical weathering}

The sum of dissolved cations was relatively low, $900 \Sigma \mu \mathrm{Eq}^{+} \mathrm{L}^{-1}$, during the peak-flow period compared to $1110 \Sigma \mu \mathrm{Eq}^{+} \mathrm{L}^{-1}$ in the early melt season and $1840 \Sigma \mu \mathrm{Eq}^{+} \mathrm{L}^{-1}$ in the late melt season (Table 9). The annual sum of dissolved cations was $990 \Sigma \mu \mathrm{Eq}^{+} \mathrm{L}^{-1}$, which is higher than the previous range from Svalbard glaciers, $280 \Sigma \mu \mathrm{Eq}^{+} \mathrm{L}^{-1}$ (austre Brøggerbreen 1992 and Erdmannbreen 1996) to $730 \Sigma \mu \mathrm{Eq}^{+} \mathrm{L}^{-1}$ (austre Brøggerbreen 2000) (calculated after Hodgkins and others, 1997; Hodson and others, 2000; Krawczyk and others, 2003). The crustal/organic solute yield was $22 \mathrm{t} \mathrm{km}^{-2} \mathrm{a}^{-1}$, assuming that no atmospheric sequestration of $\mathrm{CO}_{2}$ took place. This is in concordance with the range of yields for Svalbard glaciers $\left(11-39 \mathrm{t} \mathrm{km}^{-2} \mathrm{a}^{-1}\right.$; Hodson and others, 2000). Also, the cation-equivalent weathering rate was $322 \mathrm{\Sigma mEq}^{+} \mathrm{m}^{-2} \mathrm{a}^{-1}$, a value close to the mean cation-equivalent weathering rate of $350 \mathrm{NmEq}^{+} \mathrm{m}^{-2} \mathrm{a}^{-1}$ for Svalbard glaciers (Hodson and others, 2000). When the cation-equivalent weathering rate is related to the relatively low specific runoff of $0.34 \pm$ $0.07 \mathrm{~m} \mathrm{a}^{-1}$, the degree of crustal/organic derived solutes is expressed by the chemical weathering intensity (CWI) index (Krawczyk and others, 2003). The CWI index was $940 \pm$ $240 \Sigma \mathrm{mEq}^{+} \mathrm{m}^{-3}$, which is significantly higher than the previous range of $230 \mathrm{NmEq}^{+} \mathrm{m}^{-3}$ (Erdmannbreen 1991) to $650 \Sigma \mathrm{mEq}^{+} \mathrm{m}^{-3}$ (austre Brøggerbreen 2000) for Svalbard glaciers (Hodgkins and others, 1997; Hodson and others, 2000; Krawczyk and others, 2003), and only comparable to $\mathrm{CWI}$ indices of $940-1000 \mathrm{EmEq}^{+} \mathrm{m}^{-3}$ found for the Himalayan Batura glacier in 1999 (Hodson and others, 2002).

\section{DISCUSSION}

\section{Cold-based glacier hydrology}

Four flow paths exist at Longyearbreen: (1) a supraglacial system, (2) a lateral ice-marginal system, (3) a discrete englacial and subglacial system and (4) a distributed englacial and subglacial system. Supraglacial meltwater seepage is collected in channels, which become increasingly incised and subsequently englacial, as the channels approach the glacier margin. Hence, crevasses and moulins are only of minor importance for meltwater access to the englacial drainage system. The incision rate is controlled by the meteorological conditions and the dynamic nature of supraglacial catchment areas (Hansen, 2001). 
At Longyearbreen, the lateral margins are an integral part of the englacial and subglacial drainage system. They primarily gain meltwater from Larsbreen and glacier [14203], and secondarily from adjacent talus slopes and glacier margins. The eastern lateral channel disappears below Longyearbreen $\sim 500 \mathrm{~m}$ from the terminus, whereas the western lateral channel emanates from a portal $\sim 500 \mathrm{~m}$ from the terminus and remains subaerial.

The configuration of the englacial and subglacial discrete drainage system is relatively stable in Longyearbreen owing to its cold-based thermal regime and low mass turnover. At many places, channel geometry allows open-system water transport throughout the entire melt season, and the glacier is empty of running water in winter. Thus, the vast majority of subglacial water transport occurs from May to September in open-system channels with various tortuosities, and the connectivity between the supraglacial and subglacial drainage system is relatively restricted, as only a few crevasses and moulins exist. However, as extremophile, psychrotolerant microbes have survived at least 1100 years (Humlum and others, 2005), an englacial and subglacial distributed drainage system must also exist in order to supply water and nutrients to this microbial ecosystem. Water entering this distributed drainage system is likely to be reduced by microbial-mediated weathering processes (Bottrell and Tranter, 2002). Although relatively little is known about distributed drainage systems of cold-based glaciers, unsaturated conditions where water transport is governed by capillary flow and preferential pathways, such as in intergranular veins (Nye and Frank, 1973), are likely to dominate. Thus, distributed drainage is not restricted to the ice-bed interface, but may exist englacially (e.g. in relation to debris bands). At Scott Turnerbreen, a cold-based glacier located $12 \mathrm{~km}$ southeast of Longyearbreen, a large proglacial naled forms each winter (Hodgkins and others, 1997, 2004), indicating that the glacier either has a direct geomorphic impact by allowing water percolation through thawed subchannel sediments or has an indirect geomorphic impact by influencing the hydraulic gradient of groundwater flow in adjacent rocks. This contrasts with the drainage conditions at Longyearbreen, where no proglacial naled formation occurs. Until further research on this issue has been conducted, transient water and solute flow through the distributed drainage system or as subglacial groundwater flow is assumed negligible in comparison with the total discharge and solute fluxes.

\section{Solid-solution interactions}

All flow paths come into contact with sediments. Acquisition of crustal- and organic-derived solutes occurs in the subglacial channels (e.g. from subglacial talus deposits) on the glacier surface and moraines as meltwater interacts with glacier-transported debris, and as periglacial solid-solution interaction on the talus slopes.

\section{Seasonal chemical characteristics}

\section{Early melt season}

Seasonal changes in chemical composition and $\delta^{18} \mathrm{O}$ values in the effluent waters reflect three periods with different water productivity and accessibility to reactive rocks. During the early melt season, water originates primarily from snowmelt (low $\delta^{18} \mathrm{O}$ values), and solute concentrations are mainly a product of preferential leaching from the snowpack (high $\mathrm{Cl}^{-}$concentrations). Fluctuations in $\delta^{18} \mathrm{O}$ values and solute content are not diurnal, but last several days, and are related to air-temperature variations. High air temperatures cause high melt rates leading to low solute concentrations. Ice in periglacial areas and accretion ice formed inside the subglacial drainage system during the autumn season as transient water freezes at the floor of englacial and subglacial channels and conduits provide secondary solute contributions. Accretion ice is likely to be very solute-rich, as indicated by the water chemistry of the sample obtained inside the subglacial drainage system at the end of the ablation season (Table 2).

\section{Peak-flow period}

During the peak-flow period, the hydrochemistry is characterized by almost constant solute concentrations regardless of the diurnal cycle in discharge. This indicates that the involved reaction kinetics are fast. As water-rock contact time is low, owing to the discrete drainage network, the reactions controlling the chemical composition must occur within hours, and no constraints in access to reactive mineral surfaces exist. This suggests that the lack of filtration until late after sample collection had a limited effect on solute concentrations in this geochemical environment. This interpretation is supported by the very significant correlation between in situ conductivity measurements and solute content $\left(R^{2}=0.98\right)$. Assuming that post-sampling mineral dissolution should have significant influence on solute concentrations, we would expect this correlation to be weaker because of the lack of correlation between suspended sediment concentrations and solute content $\left(R^{2}=0.05\right)$.

High $\mathrm{SO}_{4}{ }^{2-}, \mathrm{Ca}^{2+}$ and $\mathrm{Mg}^{2+}$ concentrations, the $1: 1$ molar ratio of $\mathrm{Ca}^{2+}$ to $\mathrm{Mg}^{2+}$ and the open-system drainage configuration indicate that the first-order control of the chemical composition of the bulk water is biogeochemical sulfide oxidation coupled to dolomite $\left((\mathrm{Ca}, \mathrm{Mg}) \mathrm{CO}_{3}\right)$ dissolution under oxidizing conditions:

$$
\begin{aligned}
& 16(\mathrm{Ca}, \mathrm{Mg}) \mathrm{CO}_{3(\mathrm{~s})}+4 \mathrm{FeS}_{2(\mathrm{~s})}+15 \mathrm{O}_{2(\mathrm{aq})}+14 \mathrm{H}_{2} \mathrm{O}_{(\mathrm{I})} \rightarrow \\
& 8 \mathrm{Ca}_{(\mathrm{aq})}^{2+}+8 \mathrm{Mg}_{(\mathrm{aq})}^{2+}+16 \mathrm{HCO}_{3(\mathrm{aq})}^{-}+8 \mathrm{SO}_{4}^{2-}(\mathrm{aq}) \\
& +4 \mathrm{Fe}(\mathrm{OH})_{3(\mathrm{~s})} .
\end{aligned}
$$

The proton production by sulfide oxidation is neutralized by dissolution of dolomite increasing the $\mathrm{pH}$ level in the water. Thus, $\mathrm{pH}$ is a poor measure for the acidity of meltwater from Longyearbreen. Balance calculations using the low-temperature aqueous geochemical modelling software, PHREEQC, show that this reaction leads to $\mathrm{PCO}_{2}$ pressures higher than atmospheric pressure. As the drainage system is open, the majority of produced $\mathrm{HCO}_{3}{ }^{-}$diffuses out of solution as $\mathrm{CO}_{2}$, in addition to secondary autotrophic microbial fixation of $\mathrm{CO}_{2}$. Thus, the remaining evidence of sulfide oxidation is elevated $\mathrm{SO}_{4}{ }^{2-}, \mathrm{Ca}^{2+}$ and $\mathrm{Mg}^{2+}$ concentrations. Pyrite $\left(\mathrm{FeS}_{2}\right)$ is the most common sulfide mineral, but other ferric sulfide minerals such as marcasite $\left(\mathrm{FeS}_{2}\right.$, a polymorph of pyrite), pyrrhotite $\left(\mathrm{Fe}_{1-x} \mathrm{~S}\right.$, where $x$ is between 0 and 0.125$)$, chalcopyrite $\left(\mathrm{CuFeS}_{2}\right)$ and pentlandite $\left((\mathrm{Fe}, \mathrm{Ni})_{9} \mathrm{~S}_{8}\right)$, and metallic sulfides and gypsum $\left(\mathrm{CaSO}_{4} \cdot 2 \mathrm{H}_{2} \mathrm{O}\right)$ can be additional sources of sulfur. Saturation index calculations, using PHREEQC, indicate that the $\mathrm{SO}_{4}{ }^{2-}$ concentrations are not high enough to facilitate sulfate mineral precipitation under the $\mathrm{pH}$ conditions encountered. It is, however, possible that local conditions allow precipitation of gypsum or jarosite $\left(\mathrm{KFe}_{3}\left(\mathrm{SO}_{4}\right)_{2}(\mathrm{OH})_{6}\right)$, but this cannot be documented from the 
effluent solute composition and such precipitates have yet to be identified. Precipitates (ochres) of ferric hydroxides, which include goethite, ferrihydrites and amorphous phases, coat glaciofluvial deposits at the proglacial stream bed.

In non-photosynthetic oxidizing environments, several groups of bacteria (e.g. Beggiatoa, Thiobacillus and Microspira) oxidize reduced sulfur compounds (e.g. Perry and others, 2002) and thereby augment reaction rates (Sharp and others, 1999). In contrast, microbial-mediated sulfatereduction processes may occur at the glacier bed in areas with limited water flow such as in the hyporheic zone of subglacial channel margins (Hodson and others, 2005; Tranter and others, 2005). Hence, microorganisms can have a significant influence on glacial water chemistry (Sharp and others, 1999; Skidmore and others, 2000, 2005; Tranter and others, 2002).

Dolomite weathering accounts for $67 \%$ of the total proton production associated with sulfide oxidation, assuming that all $\mathrm{HCO}_{3}{ }^{-}$is derived from dolomite, while the remaining $33 \%$ is coupled to weathering of silicate minerals. The molar ${ }^{*} \mathrm{~K}^{+} /{ }^{*} \mathrm{Na}^{+}$ratio is 0.07 , which is in contrast to the relatively high ${ }^{*} \mathrm{~K}^{+} /{ }^{*} \mathrm{Na}^{+}$ratio of $\sim 1$ generally found in glacial runoff (Anderson and others, 1997; Anderson, 2005). This low ${ }^{*} \mathrm{~K}^{+} /{ }^{*} \mathrm{Na}^{+}$ratio indicates that incongruent weathering of alkali-feldspar $\left((\mathrm{Na}, \mathrm{K}) \mathrm{AlSi}_{3} \mathrm{O}_{8}\right)$ is more important than weathering of biotite $\left(\mathrm{K}(\mathrm{Mg}, \mathrm{Fe})_{3} \mathrm{AlSi}_{3} \mathrm{O}_{10}(\mathrm{OH})_{2}\right)$. Assuming that all ${ }^{*} \mathrm{Na}^{+}$and ${ }^{*} \mathrm{~K}^{+}$are derived from weathering of alkalifeldspar, the geochemical formula is $\mathrm{Na}_{0.93} \mathrm{~K}_{0.07} \mathrm{AlSi}_{3} \mathrm{O}_{8}$. Sulfide oxidation is either coupled to alkali-feldspar surface weathering (Equation (4)) or alkali-feldspar dissolution to a secondary solid phase (e.g. kaolinite $\left(\mathrm{Al}_{2} \mathrm{Si}_{2} \mathrm{O}_{5}(\mathrm{OH})_{4}\right)$ ) (Equation (5)):

$$
\begin{aligned}
16 \mathrm{Na}_{0.93} \mathrm{~K}_{0.07} \mathrm{AlSi}_{3} \mathrm{O}_{8(\mathrm{~s})}+4 \mathrm{FeS}_{2(\mathrm{~s})}+15 \mathrm{O}_{2(\mathrm{aq})}+14 \mathrm{H}_{2} \mathrm{O}_{(\mathrm{l})} \rightarrow \\
14.88 \mathrm{Na}_{(\mathrm{aq})}^{+}+1.12 \mathrm{~K}_{(\mathrm{aq})}^{+}+16 \mathrm{HAISi}_{3} \mathrm{O}_{8(\mathrm{~s})}+8 \mathrm{SO}_{4}^{2-}(\mathrm{aq}) \\
+4 \mathrm{Fe}(\mathrm{OH})_{3(\mathrm{~s})^{\prime}}
\end{aligned}
$$

$$
\begin{aligned}
16 \mathrm{Na}_{0.93} \mathrm{~K}_{0.07} & \mathrm{AlSi}_{3} \mathrm{O}_{8(\mathrm{~s})}+4 \mathrm{FeS}_{2(\mathrm{~s})}+15 \mathrm{O}_{2(\mathrm{aq})}+86 \mathrm{H}_{2} \mathrm{O}_{(\mathrm{l})} \rightarrow \\
14.88 \mathrm{Na}_{(\mathrm{aq})}^{+} & +1.12 \mathrm{~K}_{(\mathrm{aq})}^{+}+8 \mathrm{Al}_{2} \mathrm{Si}_{2} \mathrm{O}_{5}(\mathrm{OH})_{4(\mathrm{~s})} \\
+ & 8 \mathrm{SO}_{4(\mathrm{aq})}^{2-}+32 \mathrm{H}_{4} \mathrm{SiO}_{4(\mathrm{aq})}+4 \mathrm{Fe}(\mathrm{OH})_{3(\mathrm{~s})} .
\end{aligned}
$$

The stoichiometry of these reactions results in the same amount of solutes except for dissolved silica $\left(\mathrm{H}_{4} \mathrm{SiO}_{4}\right)$. The $\mathrm{Si}$ concentrations were often below the detection limit, indicating the silica flux was very low. Also, the complete dissolution of the primary phase in Equation (5) is significantly slower at $0^{\circ} \mathrm{C}$ than the replacement of surface cations in Equation (4). This suggests Equation (4) takes place at the expense of Equation (5). In addition, acid leaching of shales could contribute, with release of interlayer cations within clay minerals, but as the measured concentrations of $\mathrm{K}^{+}$are relatively low, weathering of shales is likely to be of minor significance compared to bulk meltwater chemistry.

\section{Late melt season}

During the late melt season, the solute concentrations were affected by diurnal variations in water transit time. This resulted in relatively high solute concentrations leading to a disproportionately high late-melt-season solute flux of $16 \%$ compared to the proportion of late-melt-season discharge of $8.6 \%$. This supports previous findings of significant solute fluxes in the late melt season at austre and vestre Brøggerbreen (e.g. Krawczyk and others, 2003).
A principal feature of late-melt-season hydrochemistry is the elevated $\mathrm{NO}_{3}{ }^{-}$concentrations, ranging between 16 and $300 \mu \mathrm{EqL}^{-1}$. In fact, the sample collected inside the subglacial channels after the cessation of discharge had a $\mathrm{NO}_{3}{ }^{-}$concentration of $430 \mu \mathrm{EqL}^{-1}$ (Table 2). Temporal variations in $\mathrm{NO}_{3}{ }^{-}$concentrations correlated with the variations of other crustal/organic-derived solutes, suggesting that the majority of the mobilized nitrogen in the latemelt-season waters is derived from nitrogen-bearing rocks. Coal and dispersed organic matter in other sedimentary and metasedimentary rocks provide a significant nitrogen pool (Holloway and Dahlgren, 2002), and natural weathering may enhance inorganic nitrogen concentrations in stream water (Holloway and others, 1998) and snowpacks (Wadham and others, 2006). For instance, the Longyearbyen coal seam has a nitrogen content of $\sim 15.200 \mathrm{mg} \mathrm{N} \mathrm{kg}^{-1}$ (Ćmiel and Fabiańska, 2004) compared to $\sim 200 \mathrm{mg} \mathrm{N} \mathrm{kg}^{-1}$ found in granites (Holloway and Dahlgren, 2002). Crustal/organic nitrogen can derive from organic matter mineralization, $\mathrm{NH}_{4}{ }^{+}$-bearing silicates, or $\mathrm{NO}_{3}{ }^{-}$or $\mathrm{NH}_{4}{ }^{+}$salts (Holloway and Dahlgren, 2002). Under aerobic environments, microbial-mediated nitrification of $\mathrm{NH}_{4}{ }^{+}$to $\mathrm{NO}_{3}{ }^{-}$may occur, providing two protons per molecule of $\mathrm{NH}_{4}{ }^{+}$to the solution:

$$
\mathrm{NH}_{4(\mathrm{aq})}^{+}+2 \mathrm{O}_{2(\mathrm{aq})} \rightarrow \mathrm{NO}_{3(\mathrm{aq})}^{-}+2 \mathrm{H}_{(\mathrm{aq})}^{+}+\mathrm{H}_{2} \mathrm{O}_{(\mathrm{l})}
$$

Beneath temperate glaciers, it is suggested that subglacial comminution of bedrock and debris enhances the exposure of nitrogen at mineral surfaces (Tranter, 2003, 2006), but since Longyearbreen is entirely cold-based this process is negligible in this environment. This suggests that cryogenic weathering controls the mechanico-chemical disintegration of local rocks creating readily oxidized reactive surfaces (Ingram and Rimstidt, 1984). The fundamental processes may be freeze-thaw and wet-dry cycling, leading to microfracturing of rocks and formation of humic acids, and ultimately water-soluble acids. The autocatalytic process of generation of heat from oxidation and wetting may accelerate oxidation rates (Ingram and Rimstidt, 1984). Also, it is likely that cryogenic weathering is not restricted to periglacial areas, but may occur at the bed and sides of subglacial channels during the early and late melt seasons. Diurnal variations in runoff and air-pressure-induced ventilation of glacial channels may control the extent of subglacial cryogenic processes, but field observations are required in order to elucidate this issue.

\section{Annual solute flux estimation methods}

The different regression and discharge-weighted procedures presented in this paper call attention to how under- and overestimation of individual ions (Table 5) lead to different seasonal and annual solute fluxes (Table 7). As most glacial hydrochemistry studies are limited to a part of the ablation season, it is important to realize how accurately individual ions are estimated (e.g. if peak-flow regression equations or peak-flow discharge-weighted-mean ion concentrations are extrapolated to the entire ablation season in order to estimate annual solute fluxes). The interval regression method (method 3) or the interval discharge-weighted-mean ion concentration method (method 5) is preferable, although it is likely that deviations will increase in glacierized catchments with rapidly changing drainage pathways and weather conditions. 


\section{CONCLUSIONS}

The hydrochemistry of bulk meltwater from Longyearbreen has high solute concentrations, in contrast to previous glacial hydrochemistry studies (see reviews in Brown, 2002; Tranter, 2003, 2006). The water quality is influenced by (1) low specific discharge; (2) no winter runoff or proglacial naled formation; (3) an entirely cold-based thermal regime; (4) reactive coal seams rich in sulfides and nitrogen-bearing minerals; (5) dolomite neutralization of acidity rather than generation of alkalinity; and (6) freeze-thaw and wet-dry processes in subglacial channels and periglacial areas.

The ablation season is divided into three periods, based on seasonal variations in water provenance and solute fluxes. During the early melt season, discharge was generated from snowmelt, and solute fluxes were characterized by leaching of ions from the snowpack. After the rapid collapse of the snowpack, discharge mainly originated from glacier ice melt related to variations in air temperature. Although diurnal variations in discharge prevailed, the inverse relationship to solute concentrations, as observed in many glacier hydrochemistry studies, was almost absent. It is suggested that this was caused by relatively rapid reaction kinetics and negligible water flow through subglacially distributed drainage pathways. Water runoff during the late melt season showed enhanced solute concentrations as discharge decreased.

Application of different annual solute flux estimation models shows that the best way to estimate annual solute fluxes from discharge is to subdivide the ablation season into intervals. For instance, extrapolation of peak-flow period data significantly underestimated both the early- and latemelt-season solute fluxes. As $16 \%$ of the solutes were evacuated during the late melt season, this period is of particular importance in glacial solute flux studies.

Solute acquisition and chemical weathering intensity at Longyearbreen are primarily controlled by the low specific runoff and the sedimentary geology with coal seams. Microbial-mediated sulfide oxidation coupled to dolomite dissolution under oxidizing conditions is the first-order chemical reaction controlling the chemical composition of bulk meltwater runoff. Of secondary importance is sulfide oxidation coupled to alkali-feldspar surface weathering. Nitrate is derived both from acid aerosols and nitrogenbearing minerals. Thus, the production of acidic drainage from coal weathering is neutralized by congruent dissolution of dolomite releasing $\mathrm{Ca}^{2+}$ and $\mathrm{Mg}^{2+}$, incongruent weathering of silicates releasing $\mathrm{Na}^{+}$and $\mathrm{K}^{+}$and exsolution of $\mathrm{CO}_{2}$ from bulk meltwaters. Only $3.8 \%$ and $0.7 \%$ of the annual solute flux are estimated to derive from sea-salt and acidaerosol deposition, respectively.

The chemical composition of bulk meltwater runoff from Longyearbreen shows new aspects of the diversity of glacierderived bulk meltwaters, and therefore highlights the importance of glacier hydrology and hydrochemistry studies in contrasting glaciological and geological environments. However, long-term interdisciplinary biogeochemical massbalance studies covering simultaneous examinations of atmospheric deposition, changes in biomass, soil and permafrost processes, chemical weathering processes and hydrological and glaciological processes are required in order to better identify and quantify individual fluxes and study interacting biogeochemical processes. A suitable location with few logistical and manpower-related difficulties is the
Longyearbreen catchment, owing to its proximity to Longyearbyen, the local university and easy access to the glacier.

\section{ACKNOWLEDGEMENTS}

We thank A. Thoisen, B. Eriksen and B. Rasmussen for laboratory assistance, R.S. Nielsen for map design and K. Bælum for field assistance. We also thank two reviewers for offering useful suggestions and criticisms. UNIS provided logistical facilities supporting the fieldwork at Longyearbreen in 2004 as part of the master thesis of M. Riger-Kusk.

\section{REFERENCES}

Anderson, S.P. 2005. Glaciers show direct linkage between erosion rate and chemical weathering fluxes. Geomorphology, 67(1-2), 147-157.

Anderson, S.P., J.I. Drever and N.F. Humphrey. 1997. Chemical weathering in glacial environments. Geology, 25(5), 399-402.

Bottrell, S.H. and M. Tranter. 2002. Sulphide oxidation under partially anoxic conditions at the bed of the Haut Glacier d'Arolla, Switzerland. Hydrol. Process., 16(12), 2363-2368.

Bringedal, A.H. 2004. Oxygen isotopes from the surface of Longyearbreen, central Spitsbergen: palaeoclimatic implications. (MSc thesis, University of Bergen.)

Brown, G.H. 2002. Glacier meltwater hydrochemistry. Appl. Geochem., 17(7), 855-883.

Christiansen, H.H., H.M. French and O. Humlum. 2005. Permafrost in the Gruve-7 mine, Adventdalen, Svalbard. Nor. Geogr. Tidsskr., 59(2), 109-115.

Ćmiel, S.R. and M.J. Fabiańska. 2004. Geochemical and petrographic properties of some Spitsbergen coals and dispersed organic matter. Int. J. Coal Geol., 57(2), 77-97.

Etzelmüller, B., R.S. Ödegård, G. Vatne, R.S. Mysterud, T. Tonning and J.L. Sollid. 2000. Glacier characteristics and sediment transfer system of Longyearbreen and Larsbreen, western Spitsbergen. Nor. Geogr. Tidsskr., 54(4), 157-168.

Førland, E.J., I. Hanssen-Bauer and P.Ø. Nordli. 1997. Climate statistics and long-term series of temperature and precipitation at Svalbard and Jan Mayen. Oslo. Det Norske Meteorologisk Institutt. (DNMI KLIMA Rapp. 21/97.)

Grønsten, H.A. 1998. Hydrological studies and simulations of a high arctic catchment: Longyearelva, Spitsbergen. (MSc thesis, University of Oslo.)

Hagen, J.O., O. Liestøl, E. Roland and T. Jørgensen. 1993. Glacier atlas of Svalbard and Jan Mayen. Nor. Polarinst. Medd. 129.

Hansen, O.H. 2001. Internal drainage of some subpolar glaciers on Svalbard. (MSc thesis, University of Bergen.)

Hodgkins, R., M. Tranter and J.A. Dowdeswell. 1997. Solute provenance, transport and denudation in a High-Arctic glacierised catchment. Hydrol. Process., 11(14), 1813-1832.

Hodgkins, R., M. Tranter and J.A. Dowdeswell. 2004. The characteristics and formation of a high-arctic proglacial icing. Geogr. Ann., Ser. A, 86(3), 265-275.

Hodson, A.J., M. Tranter and G. Vatne. 2000. Contemporary rates of chemical denudation and atmospheric $\mathrm{CO}_{2}$ sequestration in glacier basins: an Arctic perspective. Earth Surf. Process. Landf., 25(13), 1447-1471.

Hodson, A., P. Porter, A. Lowe and P. Mumford. 2002. Chemical denudation and silicate weathering in Himalayan glacier basins: Batura Glacier, Pakistan. J. Hydrol., 262(1-4), 193-208.

Hodson, A., P. Mumford and D. Lister. 2004. Suspended sediment and phosphorus in proglacial rivers: bioavailability and potential impacts upon the $P$ status of ice-marginal receiving waters. Hydrol. Process., 18(13), 2409-2422.

Hodson, A.J., P.N. Mumford, J. Kohler and P.M. Wynn. 2005. The High Arctic glacial ecosystem: new insights from nutrient budgets. Biogeochemistry, 72(2), 233-256. 
Holland, H.D. 1978. The chemistry of the atmosphere and oceans. New York, Wiley Interscience.

Holloway, J.M. and R.A. Dahlgren. 2002. Nitrogen in rock: occurrences and biogeochemical implications. Global Biogeochem. Cycles, 16(4), 1118. (10.1029/2002GB001862.)

Holloway, J.M., R.A. Dahlgren, B. Hansen and W.H. Casey. 1998. Contribution of bedrock nitrogen to high nitrate concentrations in stream water. Nature, 395(6704), 785-788.

Holm, E.B., P.J. Brandvik and E. Steinnes. 2003. Pollution in acid mine drainage from mine tailings in Svalbard, Norwegian Arctic. J. Phys. IV [Paris], 107(1), 625-628.

Hosein, R., K. Arn, P. Steinmann, T. Adatte and K.B. Föllmi. 2004. Carbonate and silicate weathering in two presently glaciated, crystalline catchments in the Swiss Alps. Geochim. Cosmochim. Acta, 68(5), 1021-1033.

Humlum, O. 2002. Modelling late 20th-century precipitation in Nordenskiöld Land, Svalbard, by geomorphic means. Nor. Geogr. Tidsskr., 56(2), 96-103.

Humlum, O., A. Instanes and J.L. Sollid. 2003. Permafrost in Svalbard: a review of research history, climatic background and engineering challenges. Polar Res., 22(2), 191-215.

Humlum, O., B. Elberling, A. Hormes, K. Fjordheim, O.H. Hansen and J. Heinemeier. 2005. Late-Holocene glacier growth in Svalbard, documented by subglacial relict vegetation and living soil microbes. Holocene, 15(3), 396-407.

Ingram, G.R. and J.D. Rimstidt. 1984. Natural weathering of coal. Fuel, 63(3), 292-296.

Jones, I.W., G. Munhoven and M. Tranter. 1999. Comparative fluxes of $\mathrm{HCO}_{3}$ and $\mathrm{Si}$ from glaciated and non-glaciated terrain during the last deglaciation. IAHS Publ. 256 (Symposium at Birmingham 1999 - Interactions between the Cryosphere, Climate and Greenhouse Gases), 267-272.

Krawczyk, W.E., B. Lefauconnier and L.-E. Pettersson. 2003. Chemical denudation rates in the Bayelva Catchment, Svalbard, in the fall of 2000. Phys. Chem. Earth, 28(28-32), 1257-1271.

Kump, L.R. and R.B. Alley. 1994. Global chemical weathering on glacial time scales. In Usselman, T.M. and W.W. Hay, eds. Material fluxes on the surface of the Earth. Washington, DC, National Research Council, 46-60.

Lemmens, M. 1978. Relations entre concentration en cations dissous et debit de l'emissaire du glacier de Tsijiore Nouve (Valais). Catena, 5(3-4), 227-236.

Lemmens, M. and M. Roger. 1978. Influence of ion exchange on dissolved load of alpine meltwaters. Earth Surf. Process. Landf., 3(2), 179-187.

Liestøl, O. 1977. Pingos, springs and permafrost in Spitsbergen. Nor. Polarinst. Årb., 1975, 7-29.

Major, H. and J. Nagy. 1972. Geology of the Adventdalen map area. Nor. Polarinst. Skr., 138

Mikucki, J.A., C.M. Foreman, B. Sattler, W.B. Lyons and J.C. Priscu. 2004. Geomicrobiology of Blood Falls: an iron-rich saline discharge at the terminus of the Taylor Glacier, Antarctica. Aquat. Chem., 10(3-4), 199-220.

Nye, J.F. and F.C. Frank. 1973. Hydrology of the intergranular veins in a temperate glacier. IASH Publ. 95 (Symposium at Cambridge 1969 - Hydrology of Glaciers), 157-161.

Perry, J.J., J.T. Staley and S. Lory. 2002. Microbial life. Sunderland, MA, Sinauer Associates.

Riger-Kusk, M. 2006. Hydrology and hydrochemistry of a High Arctic glacier: Longyearbreen, Svalbard. (MSc thesis, University of Århus.)
Sharp, M., M. Tranter, G.H. Brown and M. Skidmore. 1995. Rates of chemical denudation and $\mathrm{CO}_{2}$ drawdown in a glacier-covered alpine catchment. Geology, 23(1), 61-64.

Sharp, M., J. Parkes, B. Cragg, I.J. Fairchild, H. Lamb and M. Tranter. 1999. Widespread bacterial populations at glacier beds and their relationship to rock weathering and carbon cycling. Geology, 27(2), 107-110.

Skidmore, M.L., J.M. Foght and M.J. Sharp. 2000. Microbial life beneath a high Arctic glacier. Appl. Environ. Microbiol., 66(8), 3214-3220.

Skidmore, M., S.P. Anderson, M. Sharp, J. Foght and B.D. Lanoil. 2005. Comparison of microbial community compositions of two subglacial environments reveals a possible role for microbes in chemical weathering processes. Appl. Environ. Microbiol., 71(11), 6986-6997.

Souchez, R.A. and M.M. Lemmens. 1987. Solutes. In Gurnell, A.M. and M.J. Clark, eds. Glacio-fluvial sediment transfer: an alpine perspective. Chichester, etc., John Wiley and Sons, 285-303.

Tonning, T. 1996. Bruk av eit geografisk informasjonssystem på glasiologiske problemstillingar. Døme frå Longyearbreen og Larsbreen på Svalbard. (MSc thesis, University of Oslo.)

Tranter, M. 1996. Glacial runoff as a sink for atmospheric $\mathrm{CO}_{2}$ during the last glacial/interglacial transition. In Bottrell, S.H., ed. 4th International Symposium on the Geochemistry of the Earth's Surface, 22-28 July 1996, Ilkley. Proceedings. Leeds, University of Leeds, 709-713.

Tranter, M. 2003. Geochemical weathering in glacial and proglacial environments. In Drever, J.I., ed. Treatise on geochemistry, Vol. 5. Oxford, etc., Elsevier, 189-205.

Tranter, M. 2006. Glacial chemical weathering, runoff composition and solute fluxes. In Knight, P.G., ed. Glacier science and environmental change. Oxford, etc., Blackwell Science.

Tranter, M., M.J. Sharp, H.R. Lamb, G.H. Brown, B.P. Hubbard and I.C. Willis. 2002. Geochemical weathering at the bed of Haut Glacier d'Arolla, Switzerland - a new model. Hydrol. Process., 16(5), 959-993.

Tranter, M., M. Skidmore and J. Wadham. 2005. Hydrological controls on microbial communities in subglacial environments. Hydrol. Process., 19(4), 995-998.

Wadham, J.L., A.J. Hodson, M. Tranter and J.A. Dowdeswell. 1997. The rate of chemical weathering beneath a quiescent, surgetype, polythermal-based glacier, southern Spitsbergen, Svalbard. Ann. Glaciol., 24, 27-31.

Wadham, J.L., S. Bottrell, M. Tranter and R. Raiswell. 2004. Stable isotope evidence for microbial sulphate reduction at the bed of a polythermal high Arctic glacier. Earth Planet. Sci. Lett., 219(3-4), 341-355.

Wadham, J.L., K.R. Hallam, J. Hawkins and A. O'Connor. 2006. Enhancement of snowpack inorganic nitrogen by aerosol debris. Tellus B, 58(3), 229-241.

Wieder, R.K. and G.E. Lang. 1984. Influence of wetlands and coal mining on stream water chemistry. Water Air Soil Pollut., 23(4), 381-396.

Yde, J.C. and N.T. Knudsen. 2004. The importance of oxygen isotope provenance in relation to solute content of bulk meltwaters at Imersuaq Glacier, West Greenland. Hydrol. Process., 18(1), 125-139.

Yde, J.C., N.T. Knudsen and O.B. Nielsen. 2005. Glacier hydrochemistry, solute provenance, and chemical denudation at a surge-type glacier in Kuannersuit Kuussuat, Disko Island, West Greenland. J. Hydrol., 300(1/4), 172-187. 